\title{
Methodological Proposals for the Development of Services in a Smart City: A Literature Review
}

\author{
Joel Serey ${ }^{1}$, Luis Quezada ${ }^{1}$, Miguel Alfaro ${ }^{1}$, Guillermo Fuertes ${ }^{1,2, *} \mathbb{C}$, Rodrigo Ternero ${ }^{1,3}$, \\ Gustavo Gatica ${ }^{4}{ }^{(}$, Sebastian Gutierrez ${ }^{5,6}$ and Manuel Vargas ${ }^{1}$ (i) \\ 1 Industrial Engineering Department, University of Santiago de Chile, \\ Avenida Ecuador 3769, Santiago 9170124, Chile; joel.serey@usach.cl (J.S.); luis.quezada@usach.cl (L.Q.); \\ miguel.alfaro@usach.cl (M.A.); rodrigo.ternero@usach.cl (R.T.); manuel.vargasg@usach.cl (M.V.) \\ 2 Facultad de Ingeniería, Ciencia y Tecnología, Universidad Bernardo O’Higgins, \\ Avenida Viel 1497, Ruta 5 Sur, Santiago 8370993, Chile \\ 3 Instituto de Matemática, Física y Estadística, Universidad de las Américas, \\ Avenida Republica 71, Santiago 7500975, Chile \\ 4 Facultad de Ingeniería, Universidad Andres Bello, Antonio Varas 880, Santiago 7500971, Chile; \\ ggatica@unab.cl \\ 5 Facultad de Economía, Gobierno y Comunicaciones, Universidad Central de Chile, \\ Lord Cochrane 417, Santiago 8330507, Chile; sebastian.gutierrez@ucentral.cl \\ 6 Facultad de Ciencias, Universidad Mayor, Manuel Montt 318, Santiago 7500628, Chile \\ * Correspondence: guillermo.fuertes@usach.cl
}

Received: 20 October 2020; Accepted: 28 November 2020; Published: 8 December 2020

\begin{abstract}
This literature review analyzes and classifies methodological contributions that answer the different challenges faced by smart cities. This study identifies city services that require the use of artificial intelligence (AI); which they refer to as AI application areas. These areas are classified and evaluated, taking into account the five proposed domains (government, environment, urban settlements, social assistance, and economy). In this review, 168 relevant studies were identified that make methodological contributions to the development of smart cities and 66 AI application areas, along with the main challenges associated with their implementation. The review methodology was content analysis of scientific literature published between 2013 and 2020. The basic terminology of this study corresponds to AI, the internet of things, and smart cities. In total, 196 references were used. Finally, the methodologies that propose optimization frameworks and analytical frameworks, the type of conceptual research, the literature published in 2018, the urban settlement macro-categories, and the group city monitoring-smart electric grid, make the greater contributions.
\end{abstract}

Keywords: artificial intelligence; internet of things; city services; smart cities

\section{Introduction}

A city can define itself as intelligent when investments in social and human capital, modernization of information, communication technologies (ICT), and transport infrastructure stimulate sustainable economic growth, combined with a high quality of life and sustainable management of natural resources from participative governments [1]. Currently, the international organization for standardization (ISO) provides a set of indicators that measure progress towards a smart city. They evaluate issues regarding the quality of city services, quality of life, complex risk management, and sustainable development. The smart city concept originated from five definitions including those of the intelligent city, information city, knowledge city, digital city, and (in a similar term to smart city itself) ubiquitous city u-City. These conceptual differences have some characteristics in common with different emphases 
and scopes [2]. The integration of resources using ICT is a principle for the creation of a smart city. Large volumes of data are generated by the internet of things (IoT), supported by artificial intelligence.

The administration of city services generates big data by obtaining, analyzing, and storing information and from making it freely available. Analysis of these large volumes of data requires the continuously implementing methodological advances in all AI application areas.

According to Mathur and Modani [3], the term AI could be defined as "the science and engineering of making intelligent machines". Therefore, a machine can be defined as "intelligent" when it carries out cognitive functions, such as learning and problem solving, associated with the human mind. For Agiwal et al. [4], the IoT is seen as the most promising technology to realize the vision of connected life as it comprises a comprehensive network of electronic devices, such as computers and electrical appliances, that are capable of communicating with each other.

Smart city concepts are in constant development and are anticipated to evolve further as their application gains popularity and they are adopted more frequently [5]. According to Chamoso et al. [6], there are currently several different technological platforms that provide support to AI application areas in smart cities-examples include sentilo, smartsantander, IBM intelligent operation center, citySDK, open cities, i-SCOPE, and open source IoT platforms to name a few.

AI techniques, such as machine learning, data science, data classification, or deep learning, enable the automation of activities related to human thinking, such as decision-making, learning, classification, and problem-solving [7].

\subsection{ISO Standards for Sustainable, Smart, and Resilient Cities}

The regulations for obtaining standardized metrics, which facilitate comparison and feedback between cities, is made up of a wide family of ISO 37100 standards. One of the first of these was ISO 37120 "Sustainable cities and communities-indicators for urban area services and the quality of life", which led to the creation of two new standards: ISO 37122 [8], "indicators for smart cities" and ISO 37123 [9], "indicators for resilient cities".

Cities need quality data for decision-making and the ISO 37120: 2014 standard series [10] addresses this problem through definitions, measurements, and information mechanisms agreed upon for all cities. It also offers recommendations on what to measure and how to measure it and is the base norm for cities to create globally normalized data [11]. The ISO 37122 standard allows the design of a smart city maturity model, evaluating 80 sustainability indicators, distributed in 19 areas of analysis that converge in the six universal development dimensions of a smart city (government, infrastructure, mobility, lifestyle, economy, and environment).

ISO 37123 is the first international standard to provide a set of indicators on resilience, helping governments to determine their exposure to potential hazards and their capacity to deal with them by developing comprehensive and effective responses in disaster risk reduction. The ISO 37123 standard is complementary to the ISO 37101: 2016 [12] standard, "sustainable development in communities-management system for sustainable development". This standard was designed to help communities define sustainable development goals and establish strategies to achieve them.

In 2018, the ISO 37120 standard was updated. Moreover, 28 new indicators were added, 24 old ones were eliminated, and 10 indicators were modified. ISO 37120: 2018 [10] is composed of 104 indicators, which are classified into different topics according to the industry sectors and the services provided in the city. Services include, but are not limited to; economy, education, energy, environment and climate change, finance, governance, health, housing, population, and social conditions, recreation, security, solid waste, sport and culture, telecommunications, transport, urban/local agriculture and food security, urban planning, wastewater, and water.

To facilitate the analysis of the smart city concept, we sought to establish a novel conceptual framework summarized in Figure 1. This framework divides the smart city concept into five areas (domains, AI application areas, AI applications, AI technologies, and methodologies). 


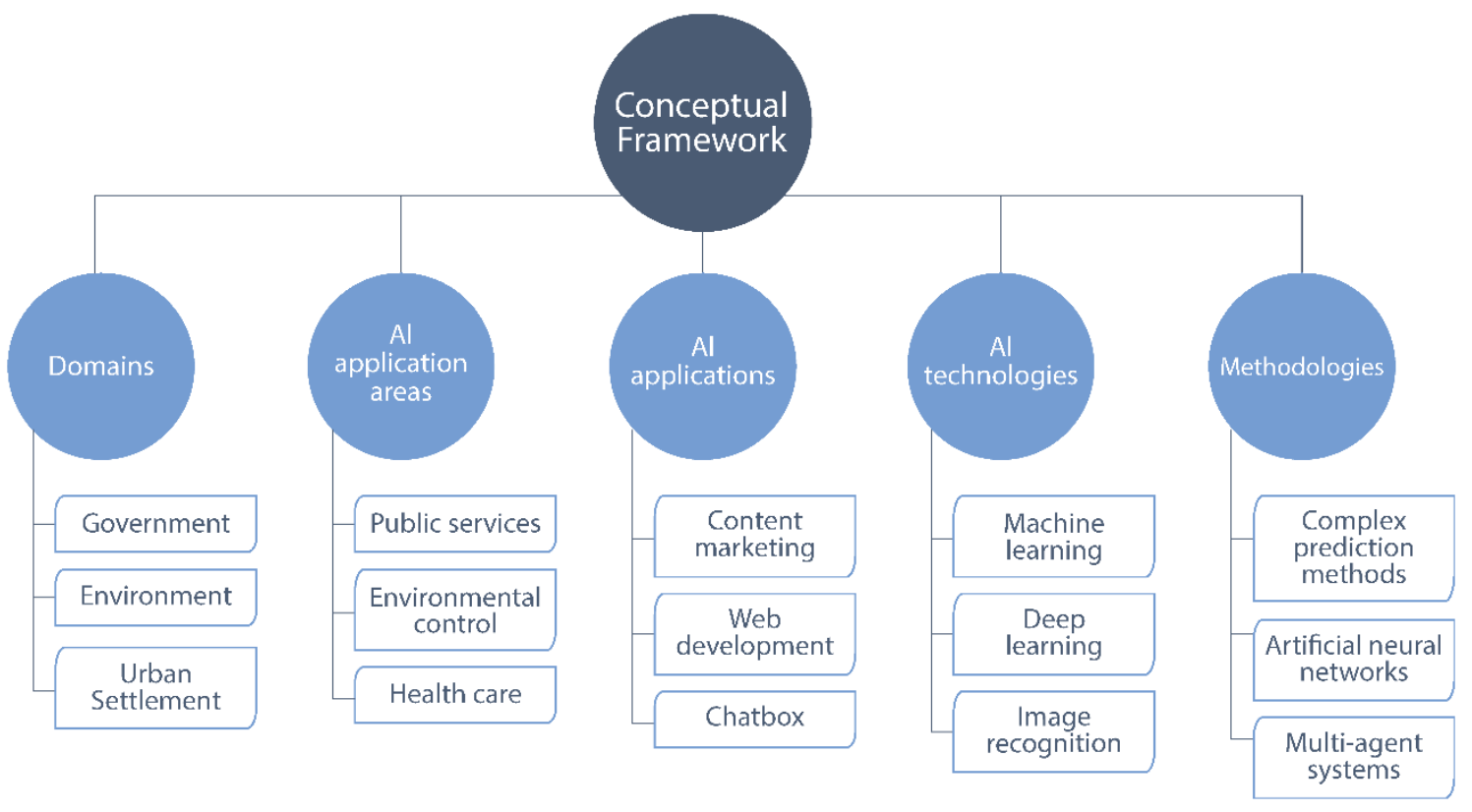

Figure 1. Schematic representation of the five study areas proposed in smart city.

The literature review of Section 4 is mainly based on numerals 1,2, and 5 of the conceptual framework. Due to the rapid growth of urban centers, some authors, such as Dellermann et al. [13], propose grouping AI applications areas by domains, which would allow us to understand and analyze the innovations and their implementations generated within new smart cities.

The literature review of the present study is divided into five sections. Section 1 has two components; the main smart city concepts and their relationship with AI and a descriptive review of ISO 37100 members and the standards for guiding cities towards becoming a smart city. Section 2 describes the methodology used. Section 3 presents a discussion regarding different proposals by different authors for the classification of domains in smart cities and classifies the aspects of the proposed AI application areas. Section 4 reviews the literature to classify each study according to the research domain, research type, and solution methodology for each of the $66 \mathrm{AI}$ application areas. Subsequently, in Section 4.6, we provide a descriptive analysis of 161 literature reviews and, finally, Section 5 presents the main conclusions of the proposed study.

\subsection{Limitations and Future Work}

This study is limited to literature framed in the area of engineering. All of the articles selected for the literature review were analyzed according to scientific contributions that provide solutions to the challenges presented by the smart city concept, together with the platforms that support technologies, such as IoT, AI, blockchain, cloud computing, knowledge automation, big data etc.

Based on the five definitions of the smart city concept mentioned in session 1, and taking into account the conceptual framework of Figure 1, future work could expand the discussions in the proposed study areas. For example, one of the definitions that needs to be expanded is the u-City concept, to know the impact generated by the advances of the AI application areas in social development, from a perspective framed in human and social capital [14-16].

It is essential to broaden the literature review, by focusing also on the advantages of a machine learning method for each city services group [17], e.g., in traffic management, machine learning provides the advantages to save the costs needed to create/adapt the heuristics to understand, predict, and manage anomalies in mobility [18]. 


\section{Methodology}

This work encompassed an extensive search of the literature of the most recent advances in methodological proposals for the development of the smart city concept published between 2013 and 2020, and was developed in four stages: (1) search of bibliography in indexed databases; (2) selection of investigations; (3) classification of investigations by domain; and (4) analysis of results. The methodology used was content analysis [19] to analyze different reverse logistics models [20], study progress advances in nanotechnology applied to smart packaging [21], propose a conceptual framework for strategic management [22], and classify AI methodological contributions with application to structural engineering [23].

The methodological proposal of this article, which includes identification, classification, and analysis in our case of smart city domains and services that require the methodological advance of AI, was used by Lee et al. [2] to evaluate exploitation level of services in different domains in the cities of Seoul and San Francisco.

Using the same methodology, the research by Lee et al. [24] identifies, classifies, and analyzes services, devices, and technologies for the development of smart city architecture. Likewise, Lee et al. [25] used it to propose a ubiquitous u-Eco ecological city architecture evaluating the convergence of IT services within the urban space.

This study is divided into macro-categories and groups. The macro-categories are represented by the five proposed domains and the groups represent the $66 \mathrm{AI}$ application areas. In turn, each group contains the methodological proposals for each AI application area, identifying their degree of development through the number of investigations

The process of reading and literature analysis was done through the google scholar search engine using the WOS-Scopus digital platforms and mainly utilizing databases such as Springer Link, EmeraldInsight, Science Direct, Wiley Online Library, Taylor \& Francis Group, and IEEE Xplore Digital Library, among others. In this study, 5600 publications in scientific journals have been reviewed, of which 161 were included in the literature review. Our main research question was: what are the main domains, city services, and important methodologies that contribute to the development of the smart city concept?

\section{Classification of AI Application Areas by Domain}

Authors such as [26-29] established numerous domains, city services, definitions, dimensions, models, and smart city paradigms. Alamsyah et al. [26] classified domains into four groups (government, citizens, businesses, and environment). The domain of government corresponds to the ability to respond efficiently to the needs of the citizen. The citizen domain focuses on activities that generate well-being. The business domain groups all the services and techniques, which enhance the added value of activities in the city. Finally, the environment domain highlights the need to create more sustainable cities (recycling models, environmental security, and quality of information).

Authors, such as Arroub et al. [27] build their smart city vision upon the quality of life of citizens, and smart city dimensions are grouped into six domains (environment, life, smart economy, government, mobility, and people). For the authors, the environment domain seeks to improve sustainability by integrating water, green spaces, wastewater infrastructure, and green energy resources. The life domain corresponds to the ability to use technology to improve the quality of life of citizens. The smart economy domain establishes synergic characteristics; innovation, social responsibility, competitiveness, digital cloud computing, and circular economy, generating value within the commercial, financial, service-based, and productive activities of the city. The government domain corresponds to the relationships, laws, regulations, practices, information, and rules that allow interaction between all interested parties. In the mobility domain, the transport systems are interconnected in real-time and there are multiple options, preserving quality service and optimization. For [30,31], the IoT and ICT allow the development of a new generation of urban traffic control and traffic management 
systems. Finally, the personal domain focuses on the importance of creativity, knowledge, learning, and education.

Oktaria and Suhardi [28] classified domains into three groups (urban settlement, social service, and economy). The urban settlement domain concentrates all the physical assets of the city (centralization and distribution of government services) and establishes the monitoring and control capacity of the city. The social service domain provides the community with social welfare (education, health, and social care) and the economy domain allows the generation of added value in the city (transport, financial services, industry and commerce, tourism, and culture).

Authors such as Raaijen and Daneva [29] classify smart city challenges into eight domains (technical infrastructure, application domains, system integration, data processing, governance and management, society and citizens, business domain, and environmental sustainability). The authors group the first four domains as technical challenges that require the capacity for innovation in the city's infrastructure. The second group is characterized by qualitative aspects such as culture, environmental protection, and government strategies capable of establishing relationships with all stakeholders.

Table 1 describes the classification structure of AI application areas in the investigations of [26-29]. Based on these investigations, we identified 66 areas where AI needs to be used and classified into five domains. Table 1 also presents 11 areas that were not studied by [26-29], which are proposed from our literature review and service needs of the residents of a smart city. Finally, the proposed classification structure in Table 1, together with the level of implementation of AI technology, allowed us to define how smart a city can be. 
Table 1. AI application areas by domains.

\begin{tabular}{|c|c|c|c|c|c|}
\hline Domain & AI Applications Areas & Alamsyah et al. [26] & Arroub et al. [27] & Oktaria and Suhardi [28] & Raaijen and Daneva [29] \\
\hline \multirow{13}{*}{ Government } & E-government and citizen participation & $\mathrm{x}$ & $x$ & $\mathrm{x}$ & \\
\hline & Transparent government & $\mathrm{x}$ & & & $\mathrm{x}$ \\
\hline & Public service & $\mathrm{x}$ & & & \\
\hline & Public safety & $x$ & & & \\
\hline & City monitoring & $\mathrm{x}$ & & & $\mathrm{x}$ \\
\hline & Emergency response & $\mathrm{x}$ & & & \\
\hline & City management & & & & \\
\hline & Facility and infrastructure provision controlling service & & & & $x$ \\
\hline & Job creation, work, and employment & & & & \\
\hline & Environmental control & & $\mathrm{X}$ & $\mathrm{X}$ & \\
\hline & Disaster management & & & $x$ & \\
\hline & Crime and disaster prevention & & & $x$ & \\
\hline & Public and city administration & & $x$ & $x$ & \\
\hline \multirow{10}{*}{ Environment } & Smart electric grid & $\mathrm{x}$ & & & $\mathrm{X}$ \\
\hline & Renewable energy & $\mathrm{x}$ & $x$ & & \\
\hline & Pollution control & $\mathrm{x}$ & $x$ & & $\mathrm{x}$ \\
\hline & Building & $\mathrm{x}$ & & & \\
\hline & Housing & $x$ & & & \\
\hline & Community & $\mathrm{x}$ & & $x$ & \\
\hline & Public space & & & & \\
\hline & Waste management & $x$ & & & \\
\hline & Resources & & $x$ & & $\mathrm{x}$ \\
\hline & Environment & & $x$ & & $\mathrm{x}$ \\
\hline \multirow{12}{*}{ Urban Settlement } & Real estate & & & $x$ & \\
\hline & Water management & $\mathrm{x}$ & & & \\
\hline & Drainage & & & & \\
\hline & Water waste management & $\mathrm{x}$ & & & \\
\hline & Environmental road infrastructure. & & & & $x$ \\
\hline & Energy & & & & $\mathrm{x}$ \\
\hline & Communication and information. & & & & \\
\hline & Utilities & & & & \\
\hline & Green open space & & $x$ & & \\
\hline & Park & & & $\mathrm{x}$ & \\
\hline & Space for the informal sector and small-medium enterprise & & & & \\
\hline & Financial service & & & & \\
\hline
\end{tabular}


Table 1. Cont.

\begin{tabular}{|c|c|c|c|c|c|}
\hline Domain & AI Applications Areas & Alamsyah et al. [26] & Arroub et al. [27] & Oktaria and Suhardi [28] & Raaijen and Daneva [29] \\
\hline \multirow{10}{*}{ Urban Settlement } & Regional information center & & & & \\
\hline & Smart city information service & & & & $x$ \\
\hline & Tourist & $x$ & & $x$ & \\
\hline & Lodging & & & $x$ & \\
\hline & Travel guidance & & & $x$ & \\
\hline & Transportation & & & $\mathrm{X}$ & \\
\hline & Road traffic control service & & & $x$ & $x$ \\
\hline & Parking service & & & & \\
\hline & Vehicle information service & & & $x$ & \\
\hline & Culture & & & $x$ & \\
\hline \multirow{10}{*}{ Social Service } & Learning and education & & & $x$ & \\
\hline & Healthcare & $\mathrm{x}$ & $x$ & $x$ & \\
\hline & Welfare and social care & & $x$ & $x$ & \\
\hline & Social service center & & & $x$ & \\
\hline & Entertainment and sport & & & $x$ & \\
\hline & Worship & & & & \\
\hline & Burial & & & $x$ & \\
\hline & Public transport & $\mathrm{x}$ & $x$ & $\mathrm{X}$ & \\
\hline & Social cohesion & $x$ & & & \\
\hline & E-Services delivery & & & $x$ & \\
\hline \multirow{11}{*}{ Economy } & Enterprise management & $x$ & & $x$ & $x$ \\
\hline & Logistics & $\mathrm{x}$ & & $\mathrm{X}$ & \\
\hline & Supply chain and commerce & $x$ & & $x$ & \\
\hline & Transaction and market & $\mathrm{x}$ & & $x$ & \\
\hline & Advertisement & $\mathrm{x}$ & & & \\
\hline & Research and policy innovation & & & $x$ & $x$ \\
\hline & Entrepreneurship & $x$ & & & \\
\hline & Agriculture & $\mathrm{x}$ & & $\mathrm{X}$ & \\
\hline & Center and payment service & & & $x$ & \\
\hline & Warehousing & & & $\mathrm{X}$ & \\
\hline & Industry & & & $x$ & \\
\hline
\end{tabular}




\section{Literature Review}

In these articles, we analyzed the research domain, research type and solution methodology. In total, there are 66 groups classified into five macro-categories (Table 1). The AI application areas in this study are derived from the different services that smart cities provide to their inhabitants [26-29]. Table 2 defines the categories research type/solution methodology, used in this study for the classification of methodological proposals.

Table 2. Summary of the categories research type/solution methodology.

\begin{tabular}{ll}
\hline \multicolumn{1}{c}{ Research Type } & \multicolumn{1}{c}{ Solution Methodology } \\
\hline $\begin{array}{l}\text { Conceptual research (CR): methodology in which } \\
\text { research is carried out by observing and analyzing } \\
\text { existing information on a given topic (conceptual } \\
\text { frameworks, theoretical studies, methodological } \\
\text { maps, among others). }\end{array}$ & $\begin{array}{l}\text { Optimization framework (OF): studies that propose } \\
\text { mathematical modeling to find better solutions or } \\
\text { adjust parameters. }\end{array}$ \\
\hline $\begin{array}{l}\text { Quantitative study (QS): studies that have } \\
\text { methodological developments with simulation } \\
\text { results, most of the time; numerical data to collect } \\
\text { concrete information, such as numbers. }\end{array}$ & $\begin{array}{l}\text { Analytical framework (AF): studies that aim to } \\
\text { organize and implement lines of inquiry to } \\
\text { account for the object of study. }\end{array}$ \\
\hline $\begin{array}{l}\text { Literature review (LR): analysis and discussion } \\
\text { by authors on a specific topic, generally scientific } \\
\text { reports (empirical, theoretical, critical, analytical, } \\
\text { or methodological). }\end{array}$ & $\begin{array}{l}\text { Data management (DM): studies that propose data } \\
\text { optimization models for decision making. }\end{array}$ \\
\hline $\begin{array}{l}\text { Case study (CS): detailed observation of a single } \\
\text { study subject or group to generalize the results and } \\
\text { knowledge obtained. }\end{array}$ & $\begin{array}{l}\text { Adaptive framework (ADF): studies that evaluate } \\
\text { the interaction and adaptation of systems with a } \\
\text { common objective. }\end{array}$ \\
\hline $\begin{array}{l}\text { Qualitative research (QR): non-numerical data } \\
\text { collection; studies based on surveys, interviews, } \\
\text { a panel of experts, among others. }\end{array}$ & $\begin{array}{l}\text { Access protocols (AP): studies that propose and } \\
\text { evaluate different communication mechanisms and } \\
\text { protocols, to share a common transmission medium. }\end{array}$ \\
\hline & $\begin{array}{l}\text { Communication framework (CF): studies that } \\
\text { propose and evaluate different } \\
\text { communication architectures. }\end{array}$ \\
\hline
\end{tabular}

The 161 selected investigations may not mention direct indicators or factors associated with AI; however, these solutions generate improved configurations that contribute to AI application areas, which is essential for the development of the smart city concept.

\subsection{Government Domain}

Current dynamics demand that public organizations provide efficient services, with greater transparency and accessibility, taking advantage of the digital revolution [32]. E-government is a paradigm shift in government management-a management concept that merges the public administration with the use of technologies, such as AI, IoT, blockchain, etc., integrated by ICT to improve the provision of services, quality of available information, simplification of administrative processes, document management, city monitoring, disaster management, and creation of channels that facilitate greater transparency and citizen participation [33].

One of the primary objectives of e-government is to bring public administration closer to citizens and encourage their participation in public decisions. In e-government, the design and management of public policies is aimed at creating public value, that is, the value created by the government by improving the provision of public services [34]. E-government is justified insofar as it expands the 
capacity of the public administration to generate public value [35]. Table 3 shows some relevant studies for the government domain.

Table 3. Literature review—methodological proposals to develop the government domain of the smart city concept.

\begin{tabular}{|c|c|}
\hline AI Application Areas & Research Domain. Research Type/Solution Methodology \\
\hline \multirow{5}{*}{$\begin{array}{l}\text { E-Government and } \\
\text { citizen participation }\end{array}$} & Big data and communities [36]. CS/AF. \\
\hline & $\begin{array}{l}\text { An analytical framework to bridge the knowledge gap by a specific } \\
\text { e-government initiative [37]. CS/AF. }\end{array}$ \\
\hline & $\begin{array}{l}\text { Characterizing the impact of GPS signal strength on power } \\
\text { consumption [38]. QS/OF. }\end{array}$ \\
\hline & Implications and pitfalls of smart earth technologies [39]. LR/AF. \\
\hline & Establishment of a digital ecosystem [40]. CS/ADF. \\
\hline \multirow{4}{*}{ Transparent government } & Intelligent governance [41]. CR/AF. \\
\hline & $\begin{array}{l}\text { An analytical framework to evaluate the role of AI, cognitive machines, } \\
\text { and viable systems [42]. QR/AF. }\end{array}$ \\
\hline & Build a general architecture for the IoT [43]. CS/AF. \\
\hline & Urban planning [44]. CS/OF. \\
\hline \multirow[b]{2}{*}{ Public services } & An optimization framework for urban trips in a smart city [45]. QS/OF. \\
\hline & $\begin{array}{l}\text { Dynamic resource partitioning for heterogeneous multi-core-based } \\
\text { cloud computing [46]. QS/AP. }\end{array}$ \\
\hline \multirow{7}{*}{ Public safety } & An analytical framework to examine cybernetic security [47]. LR/AF. \\
\hline & Informatics security [48]. QR/AF. \\
\hline & Cybernetic attack [49]. CR/HIA. \\
\hline & Crowd surveillance in a smart city [50]. QS/OF. \\
\hline & Cyber threats [51]. CR/AF. \\
\hline & Smart solutions for combat threats to safety and security [52]. LR/AF. \\
\hline & $\begin{array}{l}\text { Facial expression analysis for smart security in law-enforcement } \\
\text { services [53]. QS/OF. }\end{array}$ \\
\hline \multirow{9}{*}{ City monitoring } & Big data analysis [54]. CS/DM. \\
\hline & $\begin{array}{l}\text { Optimization framework to image classification using 5G } \\
\text { technology [55]. QS/OF. }\end{array}$ \\
\hline & Computer vision in the IoT to automate actions [56]. QS/OF. \\
\hline & Efficient management of water resources [57]. CS/OF. \\
\hline & IoT-AI in smart city model [58]. CR/AF. \\
\hline & Fault diagnosis in WSNs (reliability in the data) [59]. QS/OF. \\
\hline & $\begin{array}{l}\text { Overview of different networking architectures and protocols for smart } \\
\text { city systems [60]. CR/CF. }\end{array}$ \\
\hline & $\begin{array}{l}\text { Distributed image-retrieval method designed for a cloud-computing } \\
\text { based multi-camera system [61]. CR/OF. }\end{array}$ \\
\hline & $\begin{array}{l}\text { Challenges and opportunities to improve security and privacy in a } \\
\text { smart city [62]. LR/AF. }\end{array}$ \\
\hline \multirow{3}{*}{ Emergency responses } & Smart digital city model using real-time urban data [63]. QS/DM. \\
\hline & $\begin{array}{l}\text { Model-based runtime monitoring of smart city systems to verify smart } \\
\text { systems [64]. CR/OF. }\end{array}$ \\
\hline & Emergency treatment for cardiac arrest [65]. QS/AF. \\
\hline
\end{tabular}


Table 3. Cont.

\begin{tabular}{|c|c|}
\hline AI Application Areas & Research Domain. Research Type/Solution Methodology \\
\hline \multirow{6}{*}{ City management } & $\begin{array}{l}\text { Fault recovery mechanism when the quality of the data streams from a } \\
\text { smart city environment drops [66]. QS/ADF. }\end{array}$ \\
\hline & $\begin{array}{l}\text { An optimization framework for the prediction of the demand of patients } \\
\text { at health centers [67]. QS/OF. }\end{array}$ \\
\hline & $\begin{array}{l}\text { IoT data management for smart city development and urban } \\
\text { planning [68]. QS/DM. }\end{array}$ \\
\hline & $\begin{array}{l}\text { An analytical framework to evaluate the top ten challenges in the } \\
\text { development of the smart world [69]. CR/AF. }\end{array}$ \\
\hline & $\begin{array}{l}\text { Importance of data management and its challenges in modern life and } \\
\text { economy [70]. CR/DM. }\end{array}$ \\
\hline & Data transmission model for urban sensing [71]. CR/DM. \\
\hline \multirow{2}{*}{$\begin{array}{l}\text { Facility and infrastructure } \\
\text { provision control services }\end{array}$} & $\begin{array}{l}\text { An analytical framework to study the practical lessons from the } \\
\text { deployment and management of the IoT infrastructure [72]. CS/AF. }\end{array}$ \\
\hline & Network architecture for a smart city system design [73]. QR/AF. \\
\hline \multirow{3}{*}{$\begin{array}{l}\text { Job creation, work, } \\
\text { and employment }\end{array}$} & $\begin{array}{l}\text { Role of smart ICT in advancing infrastructure and crowdsourcing future } \\
\text { development [74]. CS/DM. }\end{array}$ \\
\hline & $\begin{array}{l}\text { Identification of intelligent, abstracted, and adaptive ways of correlating } \\
\text { and combining the various levels of information [75]. CR/ADF. }\end{array}$ \\
\hline & Environmental parameters in a smart city [76]. QS/OF. \\
\hline Disaster management & Smart energy solutions [77]. CR/AF. \\
\hline \multirow{3}{*}{ Crime and disaster prevention } & Project for the analysis of air quality post-earthquake [78]. CS/AF. \\
\hline & $\begin{array}{l}\text { Communication framework to help solve traffic overload in resource } \\
\text { sharing [79]. CR/CF. }\end{array}$ \\
\hline & $\begin{array}{l}\text { Multivariate spatiotemporal data streams to improve data } \\
\text { prediction [80]. CR/OF. }\end{array}$ \\
\hline Public and city administration & $\begin{array}{l}\text { Optimization framework to smart management of public } \\
\text { lighting [81]. CS/OF. }\end{array}$ \\
\hline
\end{tabular}

\subsection{Environment Domain}

In the long-term, the sustainability of the city is essential for its habitability and survival. An intelligent electric grid is required to connect all users and facilitate both the client consuming energy and/or delivering it to the system. Millions of electric cars connected to the grid would allow invulnerability to energy loss. The IoT would capture consumption and generation capacity in real-time and this information would be processed by AI to establish variable purchase and sale prices for each actor in the system. Likewise, an adjusted forecast of energy demand together with the information collected by sensors would allow efficient management of the electricity network in new smart cities. Roofs of houses with solar panels, micro wind turbines, hydroelectric power stations, and the tens of gigawatts of power stored in car batteries would facilitate intelligent management of the electric grid. All these technologies reduce environmental impact.

Controlling fixed and mobile pollution is another challenge for smart cities. The ability to monitor and manage polluting sources using big data would allow the intelligent reduction of energy expenditure and reduce pollution in each neighborhood of a city.

The construction of smart buildings interconnected with their physical and logical environment enables efficient management of resources, increases security and privacy, and generates more productive environments. The circular economy of interconnected areas allows positive business results to be intensified. 
Finally, communities always want better public spaces and these spaces must add value to the city. Smart benches with environmental parameter sensors, entertainment with the ability to interact with citizens, or virtual reality entertainment are some examples of how AI could be used to improve interaction in public spaces. Table 4 shows some relevant studies for the environment domain.

Table 4. Literature review-methodological proposals for the development of the environmental domain of the smart city concept.

\begin{tabular}{|c|c|}
\hline AI Application Areas & Research Domain. Research Type/Solution Methodology \\
\hline \multirow{9}{*}{ Smart electric grid } & Development of smart grid co-simulation platforms [82]. QS/OF. \\
\hline & $\begin{array}{l}\text { Integrated system with a three-tier } 5 \mathrm{G} \text { network and wireless multimedia } \\
\text { sensor networks [83]. QS/OF. }\end{array}$ \\
\hline & $\begin{array}{l}\text { The vulnerability of named data networking against content poisoning } \\
\text { attacks [84]. QS/DM. }\end{array}$ \\
\hline & Smart grid approaches and IoT applications in various fields [85]. LR/AF. \\
\hline & 5G wideband [86]. CR/OF. \\
\hline & Decision-making tool in a street lighting system [87]. CS/OF. \\
\hline & Efficient routing metric for energy-constrained devices [88]. QS/OF. \\
\hline & Location, automatic fault restoration, and isolation service dispatch problem [89]. QS/OF. \\
\hline & Photovoltaic energy distribution [90]. QS/OF. \\
\hline \multirow{3}{*}{ Renewable energy } & Optimization of renewable energy sources [91]. QS/OF. \\
\hline & Planning and energy operation management models [92]. LR/OF. \\
\hline & An optimization framework for adjusting power requirements in WSN [93]. QS/OF. \\
\hline Pollution control & Air-quality monitoring [94]. QS/CF. \\
\hline \multirow[b]{2}{*}{ Building } & Data analysis [95]. QS/HIA. \\
\hline & $\begin{array}{l}\text { An analytical framework to understand the process of building an effective } \\
\text { smart city [2]. LR/AF. }\end{array}$ \\
\hline \multirow{2}{*}{ Housing } & $\begin{array}{l}\text { An analytical framework to evaluate energy consumption, public policies, } \\
\text { and household perception of energy savings [96]. LR/AF. }\end{array}$ \\
\hline & $\begin{array}{l}\text { An analytical framework to implement smart home construction } \\
\text { requirements [97]. QR/AF. }\end{array}$ \\
\hline \multirow{4}{*}{ Community } & $\begin{array}{l}\text { Design of a communication framework for a smart city inspired by the } \\
\text { nervous system [98]. LR/CF. }\end{array}$ \\
\hline & The trustworthiness of the crowd sensed data (smartphone users) [99]. QS/OF. \\
\hline & $\begin{array}{l}\text { Design of an analytical framework for city development, sustainability, } \\
\text { and ICT [100]. LR/AF. }\end{array}$ \\
\hline & $\begin{array}{l}\text { Examining the working arrangements and commuting habits of a sample group } \\
\text { of employees from a company [101]. CS/AF. }\end{array}$ \\
\hline \multirow{2}{*}{ Waste management } & Electronic waste collection [102]. QS/OF. \\
\hline & Computing models enabled IoT to develop environmental sustainability [103]. LR/AF. \\
\hline
\end{tabular}

\subsection{Urban Settlement Domain}

This domain requires an integrative strategy for the urban systems of the city. Infrastructure for basic services such as drainage and waste management is vital for a city to function.

Energy, drainage, water, waste, communication, and information services all provide well-being. This requires delivering transparent and timely information to the end-user so they can understand the effect of their consumption. 
The current state of constructions (parks, open green space, space for informal sectors, and small and medium-sized companies) belongs to the visible infrastructure. The interaction of citizens with these services is visual; therefore, the user can differentiate the level of quality delivered by the service. AI can unite information regarding the use of services to support citizens-for example, pedestrian monitoring could provide services in places of greatest demand or need by inhabitants.

Transportation, traffic control, parking, and vehicle information services could be interconnected via category four vehicles. These vehicles can provide transportation services without a driver-a user requests the service, the public or private vehicle delivers the service and subsequently connects with AI to establish routes, share spaces, establish parking spaces, and/or find intelligent recharging points.

Finally, the city must achieve cultural integration. A smart city must prepare the population through education and must facilitate the integration of citizens and social inclusion. The school is still the main institution to create a sustainable environment in the long term. This socially protected environment can be analyzed using the multiple data streams obtained from the IoT throughout the city. In summary, AI would analyze the mood of the inhabitants, generate capacity for social inclusion, and make decisions regarding the different levels of services to improve integration. Table 5 shows some relevant studies for the urban settlement domain.

Table 5. Literature review-methodological proposals for the development of the urban settlement domain of the smart city concept.

\begin{tabular}{|c|c|}
\hline AI Application Areas & Research Domain. Research Type/Solution Methodology \\
\hline \multirow[b]{2}{*}{ Real estate } & Business intelligence project [104]. CS/AF. \\
\hline & $\begin{array}{l}\text { Statistical analysis for the evaluation of a smart real estate market [105]. } \\
\text { CS/AF.A conceptual framework for the analysis of commercial real } \\
\text { estate in smart cities [106]. CR/AF. }\end{array}$ \\
\hline \multirow{2}{*}{ Water management } & Water quality monitoring [107]. CR/ADF. \\
\hline & Water demand management [108]. QS/OF. \\
\hline \multirow{2}{*}{ Drainage } & Real-time urban drainage monitoring [109]. CS/ADF. \\
\hline & Smart urban drainage systems with real-time control [110]. QS/AF. \\
\hline Water waste management & Smart water management towards smart cities [111]. CS/AF. \\
\hline \multirow{2}{*}{$\begin{array}{l}\text { Environmental road } \\
\text { infrastructure }\end{array}$} & $\begin{array}{l}\text { Control system based on the integration of software-defined networks } \\
\text { and IoT in smart city environments [112]. QS/OF. }\end{array}$ \\
\hline & $\begin{array}{l}\text { An analytical framework to evaluate AI methods in structural } \\
\text { engineering [23]. LR/AF. }\end{array}$ \\
\hline \multirow{2}{*}{ Energy } & Intelligent control to optimize energy consumption [113]. QS/OF. \\
\hline & Adaptive traffic in hierarchical WSNs [114]. QS/HIA. \\
\hline \multirow{6}{*}{$\begin{array}{l}\text { Communication and } \\
\text { information }\end{array}$} & $\begin{array}{l}\text { Issues with network architecture in smart cities (high latency, bandwidth } \\
\text { bottlenecks, security and privacy, and scalability) [115]. CR/OF. }\end{array}$ \\
\hline & $\begin{array}{l}\text { Appropriate mechanisms for considering the users' priorities in 5G } \\
\text { ultra-dense networks [116]. QS/OF. }\end{array}$ \\
\hline & IoT/intelligent network fusion [117]. QS/OF. \\
\hline & $\begin{array}{l}\text { Discussion about state-of-the-art communication technologies and smart } \\
\text { applications [118]. LR/AF. }\end{array}$ \\
\hline & $\begin{array}{l}\text { Optimization framework to the diffusion of data packages in wireless } \\
\text { multimedia sensor networks [119]. QS/OF. }\end{array}$ \\
\hline & Detection model using wireless nanosensor networks (WNSNs) [120]. QS/OF. \\
\hline Utilities & Smart city business models [121]. LR/AF. \\
\hline
\end{tabular}


Table 5. Cont.

\begin{tabular}{|c|c|}
\hline AI Application Areas & Research Domain. Research Type/Solution Methodology \\
\hline \multirow{3}{*}{ Green open spaces } & $\begin{array}{l}\text { Integration of green space and urban forest management within } \\
\text { smart cities [122]. CR/AF. }\end{array}$ \\
\hline & An analytical framework for compact and green cities [123]. CR/AF. \\
\hline & Monitoring urban green spaces [124]. CR/AF. \\
\hline Parks & Application for monitoring tourism in national parks [125]. CR/ADF. \\
\hline \multirow{3}{*}{$\begin{array}{l}\text { Space for the informal sector } \\
\text { and small medium enterprise }\end{array}$} & $\begin{array}{l}\text { Fundamental concerns related to the technology-driven entrepreneurial } \\
\text { vision of smart cities [126]. CR/AF. }\end{array}$ \\
\hline & Impact of AI on society and firms [127]. CR/AF. \\
\hline & $\begin{array}{l}\text { The framework of big data-driven smart manufacturing, and their } \\
\text { characteristics [128]. LR/AF. }\end{array}$ \\
\hline Financial services & Smart financial format [129]. CR/OF. \\
\hline \multirow{3}{*}{ Regional information centers } & $\begin{array}{l}\text { Methods and tools for a cognition-driven and personalized } \\
\text { information system [130]. CR/OF. }\end{array}$ \\
\hline & $\begin{array}{l}\text { An analytical framework for the analysis of the information trade in } \\
\text { the IoT [131]. CR/AF. }\end{array}$ \\
\hline & 3-D analysis platform to visualize the city's information [132]. QS/ADF. \\
\hline \multirow{3}{*}{ Smart city information services } & Smart services for city improvements [133]. CR/AF. \\
\hline & $\begin{array}{l}\text { Analysis of the life-cycle of human dynamics (human behaviors and } \\
\text { activities) [134]. CR/ADF. }\end{array}$ \\
\hline & $\begin{array}{l}\text { Large scale data analytics framework for smart cities [135]. CR/AF.An adaptive } \\
\text { framework to evaluate a smart system of emergencies [136]. CR/ ADF. }\end{array}$ \\
\hline \multirow{2}{*}{ Tourism } & Smart tourism technologies [137]. CR/AF. \\
\hline & Smart and connected communities [138]. CS/AF. \\
\hline Lodging & Smart hospitality ecosystem [139]. LR/DM. \\
\hline \multirow[b]{2}{*}{ Travel guidance } & An optimization framework for classifying road obstacles [140]. QS/OF. \\
\hline & $\begin{array}{l}\text { An optimization framework for estimates of intelligent traffic time in } \\
\text { smart cities [141]. QS/OF. }\end{array}$ \\
\hline \multirow{4}{*}{ Transportation } & Vehicular communication protocol [142]. CR/CF. \\
\hline & Mobile power infrastructure planning (electric vehicle) [143]. QS/OF. \\
\hline & Big data analysis for urban traffic control [144]. QS/DM. \\
\hline & $\begin{array}{l}\text { An optimization framework to execute intelligent transportation } \\
\text { systems of systems operations [145]. QS/OF. }\end{array}$ \\
\hline \multirow{2}{*}{ Road traffic service control } & Data management for an intelligent transportation system [146]. CR/DM. \\
\hline & A pedestrian monitoring system in smart cities [147]. QS/OF. \\
\hline \multirow{3}{*}{ Parking services } & Visual parking space monitoring [148]. CR/ADF. \\
\hline & IoT smart parking system for smart cities [149]. LR/AF. \\
\hline & Instant communication to find a suitable parking place [150]. CR/AP. \\
\hline \multirow{3}{*}{ Vehicle information services } & Structure of a broadband network for processing sensory data [151]. CR/OF. \\
\hline & A common framework for urban mobility development [152]. CR/AF. \\
\hline & $\begin{array}{l}\text { An optimization framework for the mobile collection of e-waste } \\
\text { on demand [153]. QS/OF. }\end{array}$ \\
\hline \multirow{2}{*}{ Culture } & Smart city and intercultural education [154]. CR/AF. \\
\hline & Automation of audio post-production [155]. CR/AF. \\
\hline
\end{tabular}




\subsection{Social Service Domain}

Digital transformation requires public administration to plan the processes of providing social services. Currently, there is an ecosystem of technologies that directly impact the social services sector, which includes artificial intelligence, blockchain, the internet of things and the cloud, big data, and virtual and augmented reality. The characteristics of each of these technologies create a specific set of opportunities and challenges, therefore public administrators must understand which technologies will be important in each case and prepare accordingly.

The integration of sensors and nanosensors will expand the capabilities of wireless communication [156]. Smart cities require integration of all the sensors/nano sensors and cameras of the city and this information can be used by AI to detect people's facial expressions and establish the health patterns of citizens. AI will allow classifying diseases by recognizing by the tone of voice and diseases, such as Parkinson's disease, could be monitored using IoT sensors deployed around the city.

The education of the inhabitants of smart cities is essential for economic growth. AI-based instruction would enable learning objectives appropriate for everyone. Individual teaching is strengthened by peer integration and could be accomplished through AI ranking and administration.

Trade requires logistics and delivery-based e-services could sustainably facilitate the transport of goods. Drones, ground robots, public transport, and traffic control could allow the mobility of merchandise to be developed in a safe, sustainable, and low-cost manner.

Finally, welfare and social care will be the main activities of the society. The ability to establish the needs of citizens will be one of the main AI activities. Over the next decade, most of the workforce will be replaced by automation and citizens will replace paid activities with social welfare activities. Table 6 shows some relevant studies for the social service domain.

Table 6. Literature review-methodological proposals to develop the social services domain of the smart city concept.

\begin{tabular}{|c|c|}
\hline AI Application Areas & Research Domain. Research Type/Solution Methodology \\
\hline \multirow[b]{2}{*}{ Learning and education } & Development of the smart home concept for digital natives [157]. CR/AF. \\
\hline & $\begin{array}{l}\text { An analytical framework to evaluate advances in ANN and machine } \\
\text { learning [158]. LR/AF. }\end{array}$ \\
\hline \multirow{5}{*}{ Healthcare } & $\begin{array}{l}\text { Personalized ubiquitous cloud and edge-enabled networked healthcare } \\
\text { system for smart cities [159]. CS/ADF. }\end{array}$ \\
\hline & A facial expression recognition system to improve healthcare [160]. QS/OF. \\
\hline & An optimization framework for heart failure risk prediction [161]. CR/OP. \\
\hline & $\begin{array}{l}\text { An analytical framework to overview big data and smart systems } \\
\text { in healthcare [162]. LR/AF. }\end{array}$ \\
\hline & $\begin{array}{l}\text { An optimization framework for computer-assisted blood analysis to detect } \\
\text { and count leukocytes [163]. QS/OF. }\end{array}$ \\
\hline Welfare and social care & $\begin{array}{l}\text { An adaptive framework for the development of mobile applications used } \\
\text { for the prevention of potential epidemics [164]. CR/ADF. }\end{array}$ \\
\hline Social service center & $\begin{array}{l}\text { An analytical framework that determines the factors affecting e-service } \\
\text { adoption [165]. CS/AF. }\end{array}$ \\
\hline Entertainment and sport & Composition framework of semantic web services [166]. CR/OF. \\
\hline Worship & Use of ICT as a way of enhancing traditional worship practices [167]. QS/DM. \\
\hline Burial & Ecological multiple-use corridors [168]. CR/AF. \\
\hline \multirow[t]{2}{*}{ Public transport } & $\begin{array}{l}\text { Access protocols for communication between vehicles by introducing } \\
\text { moving relays [169]. QS/AP. }\end{array}$ \\
\hline & Smart controlling of traffic lights [170]. QS/OF. \\
\hline
\end{tabular}


Table 6. Cont.

\begin{tabular}{ll}
\hline AI Application Areas & Research Domain. Research Type/Solution Methodology \\
\hline \multirow{2}{*}{ Social cohesion } & Evaluation of the transformation processes into smart cities [171]. LR/AF. \\
\cline { 2 - 2 } & Deep analysis of the concept of smart social systems [172]. CR/AF. \\
\hline \multirow{3}{*}{ E-service delivery } & $\begin{array}{l}\text { Digital public services [173]. LR/AF. } \\
\text { Electronic data management system for the adoption of e-services [174]. CS/DM. }\end{array}$ \\
\cline { 2 - 2 } & $\begin{array}{l}\text { Optimization framework to a crowdsourcing solution (last mile) in an } \\
\text { e-commerce environment [175]. CR/OF. }\end{array}$ \\
\hline
\end{tabular}

\subsection{Economy Domain}

Business, commerce, and industry promote the growth of a city. Transparency, quality, and timeliness of the information and robust communication systems are required for a city to develop the capacity for economic growth.

AI-based cybersecurity provides the necessary protection for information. The main objective is to maintain real-time control of all ICT in the city. Industry, financial centers, markets, transactions, logistics, and entrepreneurship are all value-generating activities, which are empowered by efficient control of communication and data.

Innovation is based on human interaction and knowledge. The information required to improve innovation must be available to all actors. Additionally, the information must be presented via an intelligent interface to generate synergy in the innovation community.

Finally, other economic activities, such as agriculture and services, could be promoted with AI use. In agriculture, the recognition of pests by drones or vision cameras could reduce the use of pesticides. Additionally, machines for harvesting plants or fruits by robots are some of the latest real-world AI applications. Table 7 shows some relevant studies for the economics domain.

Table 7. Literature review-methodological proposals for the development of the economy domain of the smart city concept.

\begin{tabular}{|c|c|}
\hline AI Application Areas & Research Domain. Research Type/Solution Methodology \\
\hline Enterprise management & $\begin{array}{l}\text { Optimization framework of remote monitoring services for } \\
\text { anomaly detection [176]. CR/OF. }\end{array}$ \\
\hline \multirow[t]{2}{*}{ Logistics } & $\begin{array}{l}\text { An adaptive framework for IoT-enabled smart appliances under } \\
\text { industry } 4.0 \text { [177]. CS/ADF. }\end{array}$ \\
\hline & Human decision models for 4.0 industry [178]. CR/AF. \\
\hline \multirow{2}{*}{ Supply chain and commerce } & $\begin{array}{l}\text { Business model configurations in the IoT platforms for smart city } \\
\text { development [179]. CR/AF. }\end{array}$ \\
\hline & Impact of smart new technologies on retail [180]. CR/AF. \\
\hline Transaction and market & $\begin{array}{l}\text { Strategic approaches of large ICT industries (IBM, Cisco, Accenture) } \\
\text { such as technology providers [181]. CS/AF. }\end{array}$ \\
\hline \multirow[t]{2}{*}{ Advertisement } & $\begin{array}{l}\text { Design and implement a smart advertisement display board } \\
\text { prototype [182]. QS/OF. }\end{array}$ \\
\hline & Development AI technology in smart advertising processes [183]. CS/OF. \\
\hline \multirow{3}{*}{ Research and policy innovation } & A historical account of maker spaces [184]. CR/AF. \\
\hline & Economic heterogeneity of different building types [185]. CR/OF. \\
\hline & An analytical framework to analyze big urban data [186]. LR/AF. \\
\hline
\end{tabular}


Table 7. Cont.

\begin{tabular}{|c|c|}
\hline AI Application Areas & Research Domain. Research Type/Solution Methodology \\
\hline \multirow{3}{*}{ Entrepreneurship } & Model for data management [187]. CR/AF. \\
\hline & $\begin{array}{l}\text { An analytical framework for understanding the contextual development } \\
\text { of smart city initiatives [188]. CS/AF. }\end{array}$ \\
\hline & Access protocol for a smart agricultural system [189]. CR/AP. \\
\hline \multirow{2}{*}{ Center and payment service } & $\begin{array}{l}\text { Adoption blockchain to replace third-party auditors for smart } \\
\text { payments [190]. QS/OF. }\end{array}$ \\
\hline & $\begin{array}{l}\text { An optimization framework for the monetization of the IoT data using } \\
\text { smart contracts [191]. CR/OF. }\end{array}$ \\
\hline Warehousing & $\begin{array}{l}\text { An optimization framework for warehouse automation in smart } \\
\text { cities [192]. QS/OF. }\end{array}$ \\
\hline \multirow{3}{*}{ Industry } & Decentralized data analysis integration [193]. QS/OF. \\
\hline & $\begin{array}{l}\text { An analytical framework to evaluate challenges and recommendations in } \\
\text { developing smart cities and cleaner production initiatives [194]. LR/AF. }\end{array}$ \\
\hline & Smart manufacturing apps with a vendor-agnostic platform [195]. CS/OF. \\
\hline
\end{tabular}

\subsection{Descriptive Analysis of Studies}

1. Distribution of publications by research type: the most evoked research type was conceptual research (with 56 research) followed by quantitative studies (with 52), case study (with 26), literature reviews (with 24), and qualitative research (with 3) (Figure 2).

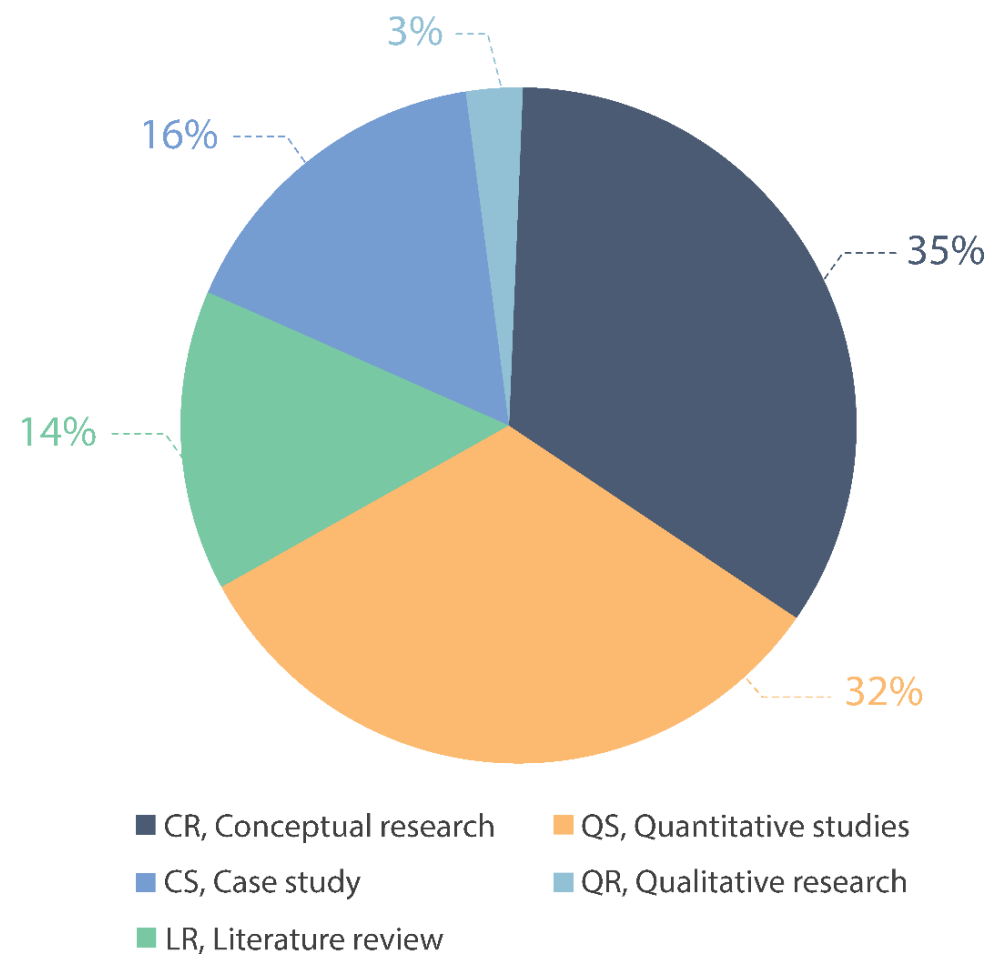

Figure 2. Distribution of studies by type of research.

2. Distribution of the solution methodologies: analysis of 161 investigations that make up the literature review shows that optimization frameworks and analytical frameworks are the most used methodological developments (with 63 research). Second, are data management (with 14). 
Third, we find the adaptive frameworks (with 11). Fourth, communication frameworks (with 4). Finally, the hierarchical information architecture and access protocols (with 3) (Figure 3).

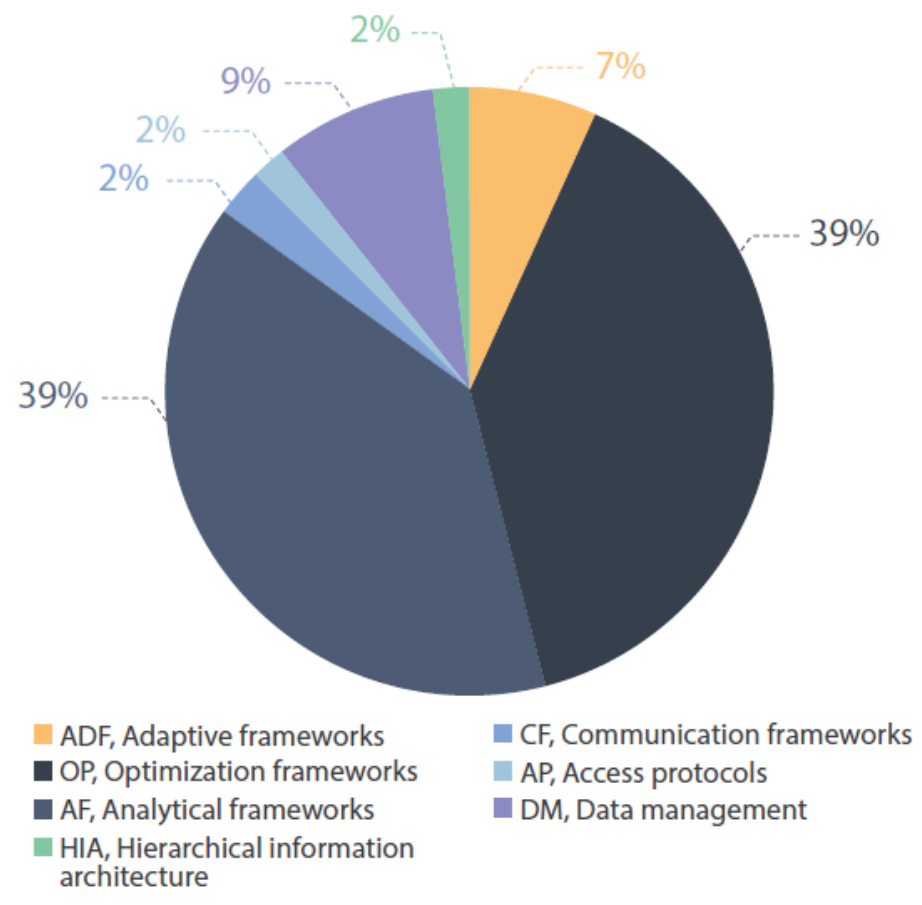

Figure 3. Distribution of the solution methodologies.

3. Several publications by year: according to [196], the number of articles using AI in smart cities increased between 2010 and 2019. This confirms the growing interest that researchers have been giving to this subject in the last years. In this study, 68 articles belonging to the literature review were published in the year 2018 (Figure 4).

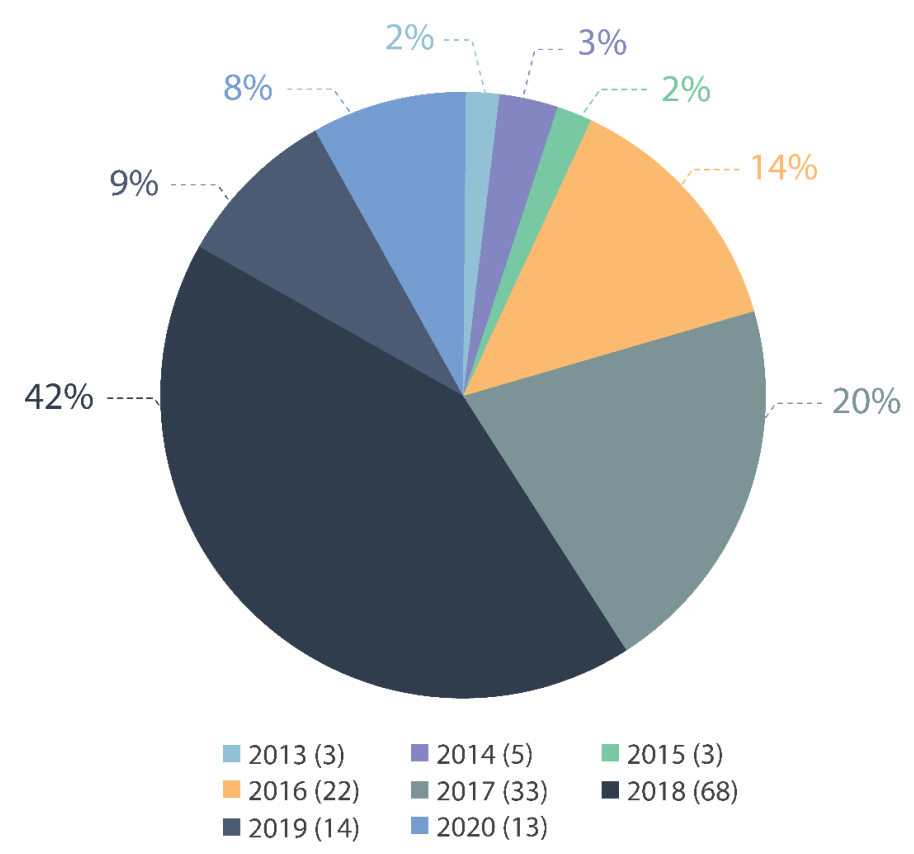

Figure 4. Number of publications years (2013-2020). 
4. Several publications by domain: in the literature review, a total of five domains with 161 articles were used. The urban settlement domain was the greatest contribution (with 53 research), followed by the government domain (with 46), environment domain (with 23), economy domain (with 20), and the social service domain (with 19) (Figure 5).

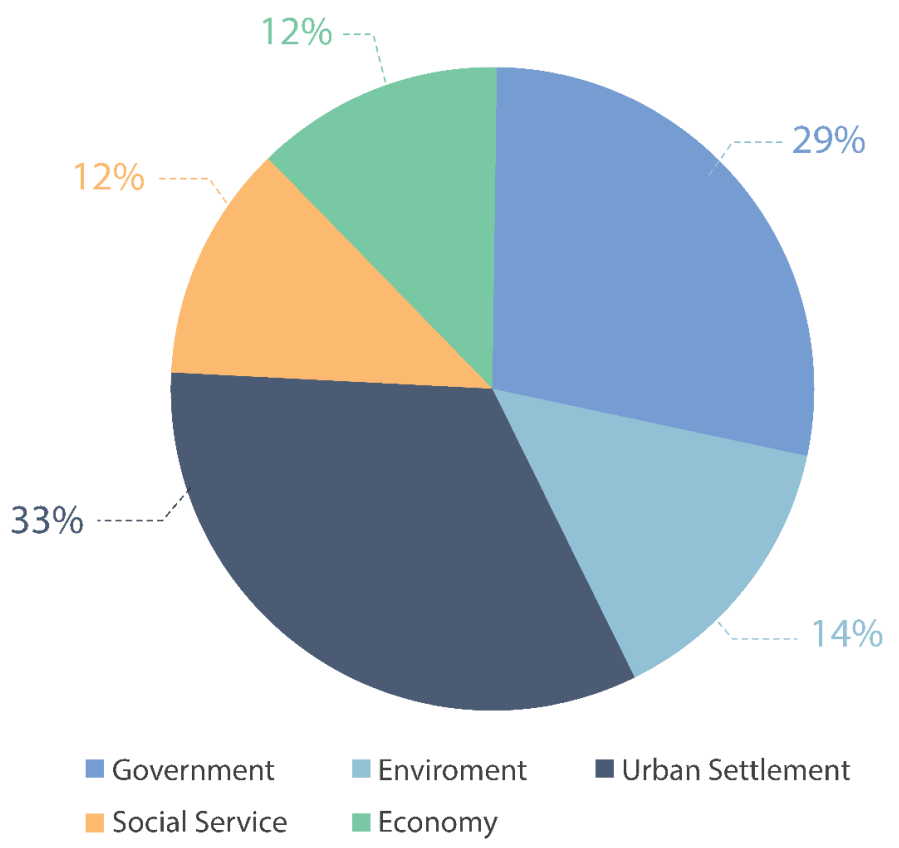

Figure 5. Number of publications by domain.

5. AI application areas in smart cities: according to our literature review, seven areas of AI application make the greatest methodological contributions. As depicted in Figure 6, the two most important are: city monitoring-smart electric grid (with 9 research), followed by public safety (with 7), communication and information-city management (with 6) and e-government and citizen participation-healthcare (with 5).

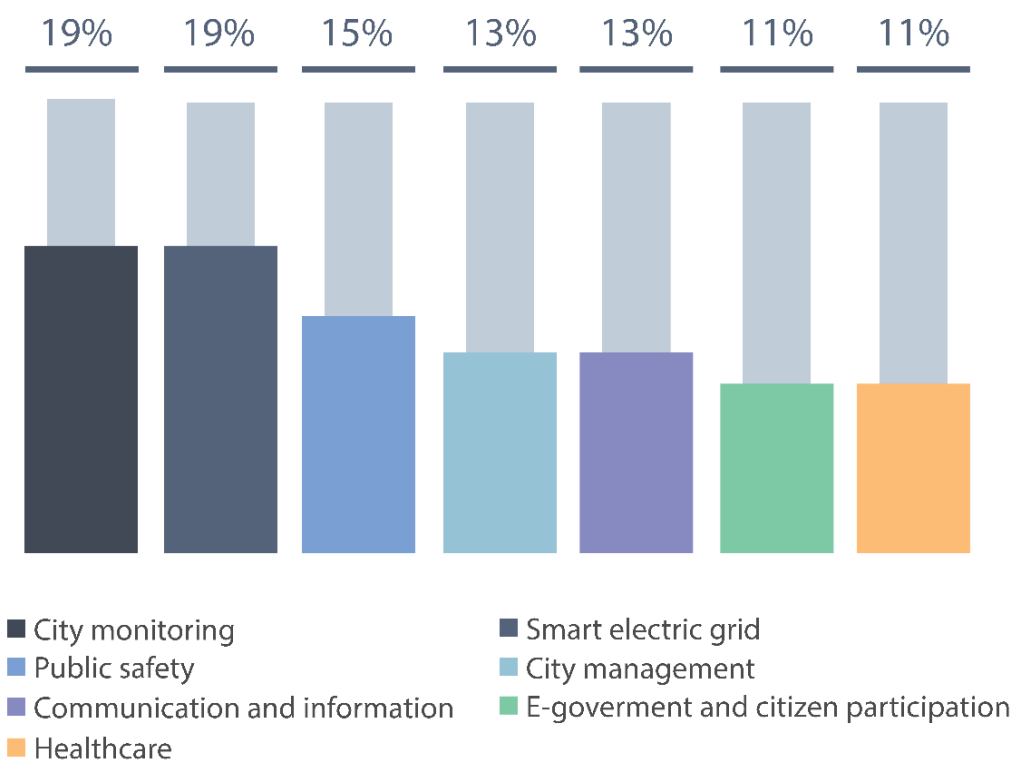

Figure 6. Distribution of the seven principal AI application areas. 


\section{Conclusions}

This literature review discusses different challenges and solutions that AI presents for the development of smart cities. However, the solutions have different smart city concepts that do not necessarily include AI (business intelligence projects, IoT, blockchain, cloud computing, knowledge automation, platforms of technological support, big data analysis, among others) that ultimately make up improved solutions with direct application to smart cities. The extensive literature review was carried out between the years (2013-2020).

In total, 196 references were used. The majority of these involved methodologies proposed optimization frameworks, conceptual research, and urban settlement domains. Moreover, 161 studies made relevant methodological contributions. Keywords, such as artificial intelligence, internet of things, and smart cities were used.

A set of five domains with $66 \mathrm{AI}$ application areas was proposed in this review. These areas allow the adequate development of sustainable and habitable smart cities. The smart city trend is to integrate available AI capabilities into all city settings; from the administration and government through to the water and energy distribution of the entire city, using the IoT and ICTs; facilitating the implementation of $\mathrm{AI}$ in all city domains.

The main communications problem is cybersecurity (privacy and external security-attacks), causing great damage to the operation of the city's domains. Emergency services, security, electricity, gas and water services, public transportation, and recycling are also all potentially vulnerable to third party interests to achieve economic benefits.

Through AI, the safety of people and the automation of crime control processes will allow citizen control capabilities and reduce crime. AI can recognize people with real-time images, analysis of people's behavior in public spaces, control goods in congested spaces (supermarkets, streets, or parks), and data processing city sensors. This generates positive effects on smart city citizens; developing safe environments that actively deter crime.

The use of AI improves the coverage and quality of social services. Health and education present trends and applications of great impact, ICT multiplies teaching capacity in schools and universities, and AI facilitates the diagnosis and control of diseases and virtual teaching. The administration and decision-making regarding hospital capacities are the main AI benefits in social services, improving the quality of life of smart city citizens.

There are many technical challenges associated with the development of smart cities that interconnect all AI application areas. The architecture of the systems must be open and scalable, improving the integration and optimization of new systems. These must have the ability to handle different data formats to correctly develop big data and transparency of information is essential to achieve sustained growth over time. The continuous supply of water and energy is also essential to sustain life in a smart city.

Collaboration between all city actors requires a technological base capable of integrating the domains with AI application areas. This integration improves the ability to achieve a sustainable and citizen-friendly city. AI must be adopted by society and it must be open, decisive, transparent, and participatory. Social validation of AI is essential to positively impact and ensure the economic growth of smart cities.

Finally, this study shows the great methodological challenges associated with the constant development of the smart city concept.

Funding: This research received no external funding.

Acknowledgments: This research was supported by DICYT (Scientific and Technological Research Bureau) of the University of Santiago of Chile (USACH) and the Department of Industrial Engineering. Project FONDEF IT17M10012: "Multiuser VLC for Underground Mining".

Conflicts of Interest: The authors declare that there is no conflict of interest regarding the publication of this article. 


\section{References}

1. Caragliu, A.; Del Bo, C.; Nijkamp, P. Smart cities in Europe. J. Urban Technol. 2011, 18, 65-82. [CrossRef]

2. Lee, J.H.; Hancock, M.G.; Hu, M.-C. Towards an effective framework for building smart cities: Lessons from Seoul and San Francisco. Technol. Forecast. Soc. Chang. 2014, 89, 80-99. [CrossRef]

3. Mathur, S.; Modani, U.S. Smart city-A gateway for artificial intelligence in India. In Proceedings of the IEEE Student's Conference on Electrical, Electronics and Computer Science, Bhopal, India, 5-6 March 2016; Institute of Electrical and Electronics Engineers Inc.: New York, NY, USA.

4. Agiwal, M.; Saxena, N.; Roy, A. Towards connected living: 5G enabled internet of things (IoT). IETE Tech. Rev. 2019, 36, 190-202. [CrossRef]

5. Allam, Z.; Dhunny, Z.A. On big data, artificial intelligence and smart cities. Cities 2019, 89, 80-91. [CrossRef]

6. Chamoso, P.; González-Briones, A.; Rodríguez, S.; Corchado, J.M. Tendencies of Technologies and Platforms in Smart Cities: A State-of-the-Art Review. Wirel. Commun. Mob. Comput. 2018, 2018, 1-17. [CrossRef]

7. Agrawal, A.; Gans, J.; Goldfarb, A. Prediction Machines: The Simple Economics of Artificial Intelligence; Harvard Business Press: Boston, UK, 2018.

8. ISO. "ISO 37122," Sustainable Cities and Communities-Indicators for Smart Cities. 2019. Available online: https://www.iso.org/obp/ui/\#iso:std:iso:37122:ed-1:v1:en (accessed on 8 September 2020).

9. ISO. "ISO 37123:2019," Sustainable Cities and Communities-Indicators for Resilient Cities. 2019. Available online: https://www.iso.org/obp/ui/\#iso:std:70428:en (accessed on 8 September 2020).

10. ISO. "ISO 37120:2014-2018," Sustainable Cities and Communities-Indicators for City Services and Quality of Life. 2018. Available online: https:/www.iso.org/obp/ui/\#iso:std:iso:37120:ed-1:v1:en (accessed on 8 September 2020).

11. Bencke, L.; Cechinel, C.; Munoz, R. Automated classification of social network messages into smart cities dimensions. Futur. Gener. Comput. Syst. 2020, 109, 218-237. [CrossRef]

12. ISO. "ISO 37101:2016," Sustainable Development in Communities-Management System for Sustainable Development. 2016. Available online: https://www.iso.org/obp/ui/\#iso:std:iso:37101:ed-1:v1:en (accessed on 8 September 2020).

13. Dellermann, D.; Ebel, P.; Söllner, M.; Leimeister, J.M. Hybrid intelligence. Bus. Inf. Syst. Eng. 2019, 61, 637-643. [CrossRef]

14. Yu, J.; Wen, Y.; Jin, J.; Zhang, Y. Towards a service-dominant platform for public value co-creation in a smart city: Evidence from two metropolitan cities in China. Technol. Forecast. Soc. Chang. 2019, 142, 168-182. [CrossRef]

15. Wirtz, B.W.; Müller, W.M.; Schmidt, F. Public smart service provision in smart cities: A case-study-based approach. Int. J. Public Adm. 2020, 43, 499-516. [CrossRef]

16. Sancino, A.; Hudson, L. Leadership in, of, and for smart cities-Case studies from Europe, America, and Australia. Public Manag. Rev. 2020, 22, 701-725. [CrossRef]

17. Ullah, Z.; Al-Turjman, F.; Mostarda, L.; Gagliardi, R. Applications of artificial intelligence and machine learning in smart cities. Comput. Commun. 2020, 154, 313-323. [CrossRef]

18. Alfeo, A.L.; Cimino, M.G.C.A.; Egidi, S.; Lepri, B.; Pentland, A.; Vaglini, G. Stigmergy-based modeling to discover urban activity patterns from positioning data. In Proceedings of the International Conference on Social Computing, Behavioral-Cultural Modeling and Prediction and Behavior Representation in Modeling and Simulation, Washington DC, USA, 5-8 July 2017; Springer: Cham, Switzerland, 2017; Volume 10354, pp. $292-301$.

19. Lopez, F. El análisis de contenido como método de investigación. Rev. Educ. 2002, 4, 167-180.

20. Banguera, L.; Sepulveda, J.M.; Fuertes, G.; Carrasco, R.; Vargas, M. Reverse and inverse logistic models for solid waste management. S. Afr. J. Ind. Eng. 2017, 28, 120-132. [CrossRef]

21. Fuertes, G.; Soto, I.; Carrasco, R.; Vargas, M.; Sabattin, J.; Lagos, C. Intelligent packaging systems: Sensors and nanosensors to monitor food quality and safety. J. Sens. 2016, 1-8. [CrossRef]

22. Fuertes, G.; Alfaro, M.; Vargas, M.; Gutierrez, S.; Ternero, R.; Sabattin, J. Conceptual Framework for the Strategic Management: A Literature Review—Descriptive. J. Eng. 2020, 2020, 1-21. [CrossRef]

23. Salehi, H.; Burgueño, R. Emerging artificial intelligence methods in structural engineering. Eng. Struct. 2018, 171, 170-189. [CrossRef]

24. Lee, J.H.; Phaal, R.; Lee, S.H. An integrated service-device-technology roadmap for smart city development. Technol. Forecast. Soc. Chang. 2013, 80, 286-306. [CrossRef] 
25. Lee, S.H.; Han, J.H.; Leem, Y.T.; Yigitcanlar, T. Towards ubiquitous city: Concept, planning, and experiences in the Republic of Korea. In Knowledge-Based Urban Development Planning and Applications in the Information Era; IGI Global: Hershey, PA, USA, 2008; pp. 148-170.

26. Alamsyah, N.; Susanto, T.D.; Chou, T.C. A comparison study of smart city in Taipei and Surabaya. In Proceedings of the International Conference on ICT for Smart Society, Surabaya, Indonesia, 20-21 July 2016; Institute of Electrical and Electronics Engineers Inc.: New York, NY, USA, 2016; pp. 111-118.

27. Arroub, A.; Zahi, B.; Sabir, E.; Sadik, M. A literature review on smart cities: Paradigms, opportunities and open problems. In Proceedings of the IEEE International Conference on Wireless Networks and Mobile Communications, Fez, Morocco, 26-29 October 2016; IEEE: New York, NY, USA, 2016; pp. 180-186.

28. Oktaria, D.S.; Kurniawan, N.B. Smart city services: A systematic literature review. In Proceedings of the International Conference on Information Technology Systems and Innovation, Bandung, Indonesia, 23-24 October 2017; Institute of Electrical and Electronics Engineers Inc.: New York, NY, USA, 2017; pp. 206-213.

29. Raaijen, T.; Daneva, M. Depicting the smarter cities of the future: A systematic literature review \& field study. In Proceedings of the IEEE Smart Cities Symposium Prague, Prague, Czech Republic, 25-26 May 2017; Institute of Electrical and Electronics Engineers Inc.: New York, NY, USA, 2017.

30. Wang, X.; Ning, Z.; Hu, X.; Wang, L.; Hu, B.; Cheng, J.; Leung, V.C.M. Optimizing content dissemination for real-time traffic management in large-scale internet of vehicle systems. IEEE Trans. Veh. Technol. 2019, 68, 1093-1105. [CrossRef]

31. Musolino, G.; Rindone, C.; Polimeni, A.; Vitetta, A. Planning urban distribution center location with variable restocking demand scenarios: General methodology and testing in a medium-size town. Transp. Policy 2019, 80, 157-166. [CrossRef]

32. Engin, Z.; van Dijk, J.; Lan, T.; Longley, P.A.; Treleaven, P.; Batty, M.; Penn, A. Data-driven urban management: Mapping the landscape. J. Urban Manag. 2020, 9, 140-150. [CrossRef]

33. Palaco, I.; Park, M.J.; Kim, S.K.; Rho, J.J. Public-private partnerships for e-government in developing countries: An early stage assessment framework. Eval. Program Plann. 2019, 72, 205-218. [CrossRef] [PubMed]

34. Scholta, H.; Mertens, W.; Kowalkiewicz, M.; Becker, J. From one-stop shop to no-stop shop: An e-government stage model. Gov. Inf. Q. 2019, 36, 11-26. [CrossRef]

35. Twizeyimana, J.D.; Andersson, A. The public value of e-government-A literature review. Gov. Inf. Q. 2019, 36, 167-178. [CrossRef]

36. Ianuale, N.; Schiavon, D.; Capobianco, E. Smart cities, big data, and communities: Reasoning from the viewpoint of attractors. IEEE Access 2016, 4, 41-47. [CrossRef]

37. Benmansour, N.A.; Lari, N.A.; Shockley, B. Exploring local governance and e-services in Qatar. Int. J. Public Adm. Digit. Age 2019, 6, 1-13. [CrossRef]

38. Tawalbeh, L.A.; Basalamah, A.; Mehmood, R.; Tawalbeh, H. Greener and smarter phones for future cities: Characterizing the impact of GPS signal strength on power consumption. IEEE Access 2016, 4, 858-868. [CrossRef]

39. Bakker, K.; Ritts, M. Smart earth: A meta-review and implications for environmental governance. Glob. Environ. Chang. 2018, 52, 201-211. [CrossRef]

40. Mettler, T. The road to digital and smart government in Switzerland. In Swiss Public Administration; Palgrave Macmillan: Cham, Switzerland, 2019; pp. 175-186.

41. Lin, Y. A comparison of selected western and Chinese smart governance: The application of ICT in governmental management, participation and collaboration. Telecomm. Policy 2018, 42, 800-809. [CrossRef]

42. Casares, A.P. The brain of the future and the viability of democratic governance: The role of artificial intelligence, cognitive machines, and viable systems. Futures 2018, 103, 5-16. [CrossRef]

43. Zanella, A.; Bui, N.; Castellani, A.; Vangelista, L.; Zorzi, M. Internet of things for smart cities. IEEE Internet Things J. 2014, 1, 22-32. [CrossRef]

44. Varghese, P. Exploring other concepts of smart-cities within the urbanising Indian context. Procedia Technol. 2016, 24, 1858-1867. [CrossRef]

45. Logesh, R.; Subramaniyaswamy, V.; Vijayakumar, V.; Gao, X.Z.; Indragandhi, V. A hybrid quantum-induced swarm intelligence clustering for the urban trip recommendation in smart city. Futur. Gener. Comput. Syst. 2018, 83, 653-673. [CrossRef] 
46. Jia, G.; Han, G.; Jiang, J.; Sun, N.; Wang, K. Dynamic resource partitioning for heterogeneous multi-core-based cloud computing in smart cities. IEEE Access 2016, 4, 108-118. [CrossRef]

47. Parasol, M. The impact of China's 2016 cyber security law on foreign technology firms, and on China's big data and smart city dreams. Comput. Law Secur. Rev. 2018, 34, 175-179. [CrossRef]

48. Aldairi, A.; Tawalbeh, L. Cyber security attacks on smart cities and associated mobile technologies. Procedia Comput. Sci. 2017, 109, 1086-1091. [CrossRef]

49. Wu, J.; Ota, K.; Dong, M.; Li, C. A hierarchical security framework for defending against sophisticated attacks on wireless sensor networks in smart cities. IEEE Access 2016, 4, 416-424. [CrossRef]

50. Kumar, S.; Datta, D.; Singh, S.K.; Sangaiah, A.K. An intelligent decision computing paradigm for crowd monitoring in the smart city. J. Parallel Distrib. Comput. 2018, 118, 344-358. [CrossRef]

51. Heartfield, R.; Loukas, G.; Budimir, S.; Bezemskij, A.; Fontaine, J.R.J.; Filippoupolitis, A.; Roesch, E. A taxonomy of cyber-physical threats and impact in the smart home. Comput. Secur. 2018, 78, 398-428. [CrossRef]

52. Srivastava, S.; Bisth, A.; Narayan, N. Safety and security in smart cities using artificial intelligence-a review. In Proceedings of the IEEE International Conference on Cloud Computing, Data Science \& Engineering, Noida, India, 12-13 January 2017; Volume 6, pp. 130-133.

53. Sajjad, M.; Nasir, M.; Ullah, F.U.M.; Muhammad, K.; Sangaiah, A.K.; Baik, S.W. Raspberry Pi assisted facial expression recognition framework for smart security in law-enforcement services. Inf. Sci. 2018, 479, 416-431. [CrossRef]

54. Ng, S.T.; Xu, F.J.; Yang, Y.; Lu, M. A master data management solution to unlock the value of big infrastructure data for smart, sustainable and resilient city planning. Procedia Eng. 2017, 196, 939-947. [CrossRef]

55. Hossain, M.S.; Muhammad, G.; Amin, S.U. Improving consumer satisfaction in smart cities using edge computing and caching: A case study of date fruits classification. Futur. Gener. Comput. Syst. 2018, 88, 333-341. [CrossRef]

56. García, C.G.; Meana-Llorián, D.; Pelayo G-Bustelo, B.C.; Cueva Lovelle, J.M.; Garcia-Fernandez, N. Midgar: Detection of people through computer vision in the internet of hings scenarios to improve the security in smart cities, smart towns, and smart homes. Futur. Gener. Comput. Syst. 2017, 76, 301-313. [CrossRef]

57. Kulkarni, P.; Farnham, T. Smart City wireless connectivity considerations and cost analysis: Lessons learnt from smart water case studies. IEEE Access 2016, 4, 660-672. [CrossRef]

58. Chatterjee, S.; Kar, A.K.; Gupta, M.P. Success of IoT in smart cities of India: An empirical analysis. Gov. Inf. Q. 2018, 35, 349-361. [CrossRef]

59. Mohapatra, A.D.; Sahoo, M.N.; Sangaiah, A.K. Distributed fault diagnosis with dynamic cluster-head and energy efficient dissemination model for smart city. Sustain. Cities Soc. 2018, 43, 624-634. [CrossRef]

60. Jawhar, I.; Mohamed, N.; Al-Jaroodi, J. Networking architectures and protocols for smart city systems. J. Internet Serv. Appl. 2018, 9, 1-16. [CrossRef]

61. Yang, J.; Jiang, B.; Song, H. A distributed image-retrieval method in multi-camera system of smart city based on cloud computing. Futur. Gener. Comput. Syst. 2018, 81, 244-251. [CrossRef]

62. Cui, L.; Xie, G.; Qu, Y.; Gao, L.; Yang, Y. Security and privacy in smart cities: Challenges and opportunities. IEEE Access 2018, 6, 46134-46145. [CrossRef]

63. Rathore, M.M.; Paul, A.; Hong, W.H.; Seo, H.C.; Awan, I.; Saeed, S. Exploiting IoT and big data analytics: Defining smart digital city using real-time urban data. Sustain. Cities Soc. 2018, 40, 600-610. [CrossRef]

64. Incki, K.; Ari, I. Model-based runtime monitoring of smart city systems. Procedia Comput. Sci. 2018, 134, 75-82. [CrossRef]

65. Samani, H.; Zhu, R. Robotic automated external defibrillator ambulance for emergency medical service in smart cities. IEEE Access 2016, 4, 268-283. [CrossRef]

66. Sasu, L.; Puiu, D.; Nechifor, S. Fault recovery mechanism for smart city environments. In Proceedings of the IEEE International Conference on Intelligent Engineering Systems, Budapest, Hungary, 30 June-2 July 2016; pp. 57-62.

67. Quero, J.M.; Medina, M.A.L.; Hidalgo, A.S.; Espinilla, M. Predicting the urgency demand of COPD patients from environmental sensors within smart cities with high-environmental sensitivity. IEEE Access 2018, 6, 25081-25089. [CrossRef]

68. Rathore, M.M.; Ahmad, A.; Paul, A.; Rho, S. Urban planning and building smart cities based on the internet of things using big data analytics. Comput. Netw. 2016, 101, 63-80. [CrossRef] 
69. Ma, J.; Zheng, Y.; Ning, H.; Yang, L.T.; Huang, R.; Liu, H.; Mu, Q.; Yau, S.S. Top challenges for smart worlds: A report on the top 10Cs forum. IEEE Access 2015, 3, 2475-2480. [CrossRef]

70. Iqbal, R.; Doctor, F.; More, B.; Mahmud, S.; Yousuf, U. Big data analytics: Computational intelligence techniques and application areas. Technol. Forecast. Soc. Chang. 2018, 1-13. [CrossRef]

71. Rolim, C.O.; Rossetto, A.G.; Leithardt, V.R.Q.; Borges, G.A.; Geyer, C.F.R.; dos Santos, T.F.M.; Souza, A.M. Situation awareness and computational intelligence in opportunistic networks to support the data transmission of urban sensing applications. Comput. Netw. 2016, 111, 55-70. [CrossRef]

72. Sotres, P.; Santana, J.R.; Sanchez, L.; Lanza, J.; Munoz, L. Practical lessons from the deployment and management of a smart city internet-of-things infrastructure: The smartsantander testbed case. IEEE Access 2017, 5, 14309-14322. [CrossRef]

73. Habibzadeh, H.; Soyata, T.; Kantarci, B.; Boukerche, A.; Kaptan, C. Sensing, communication and security planes: A new challenge for a smart city system design. Comput. Netw. 2018, 144, 163-200. [CrossRef]

74. Rice, J.; Martin, N. Smart infrastructure technologies: Crowdsourcing future development and benefits for Australian communities. Technol. Forecast. Soc. Chang. 2018, 1-10. [CrossRef]

75. Kousiouris, G.; Akbar, A.; Sancho, J.; Ta-shma, P.; Psychas, A.; Kyriazis, D.; Varvarigou, T. An integrated information lifecycle management framework for exploiting social network data to identify dynamic large crowd concentration events in smart cities applications. Futur. Gener. Comput. Syst. 2018, 78, 516-530. [CrossRef]

76. Wu, M.; Xiong, N.N.; Tan, L. An intelligent adaptive algorithm for environment parameter estimation in smart cities. IEEE Access 2018, 6, 23325-23337. [CrossRef]

77. Dincer, I.; Acar, C. Smart energy solutions with hydrogen options. Int. J. Hydrogen Energy 2018, 43, 8579-8599. [CrossRef]

78. Marek, L.; Campbell, M.; Bui, L. Shaking for innovation: The (re) building of a (smart) city in a post disaster environment. Cities 2017, 63, 41-50. [CrossRef]

79. Kunst, R.; Avila, L.; Pignaton, E.; Bampi, S.; Rochol, J. Improving network resources allocation in smart cities video surveillance. Comput. Netw. 2018, 134, 228-244. [CrossRef]

80. Kotevska, O.; Kusne, A.G.; Samarov, D.V.; Lbath, A.; Battou, A. Dynamic network model for smart city data-loss resilience case study: City-to-city network for crime analytics. IEEE Access 2017, 5, 20524-20535. [CrossRef]

81. De Paz, J.F.; Bajo, J.; Rodríguez, S.; Villarrubia, G.; Corchado, J.M. Intelligent system for lighting control in smart cities. Inf. Sci. 2016, 372, 241-255. [CrossRef]

82. Shum, C.; Member, S.; Lau, W.; Member, S. Co-simulation of distributed smart grid software using direct-execution simulation. IEEE Access 2018, 6, 20531-20544. [CrossRef]

83. Vo, N.S.; Duong, T.Q.; Guizani, M.; Kortun, A. 5G optimized caching and downlink resource sharing for smart cities. IEEE Access 2018, 6, 31457-31468. [CrossRef]

84. Hu, X.; Gong, J.; Cheng, G.; Zhang, G.; Fan, C. Mitigating content poisoning with name-key based forwarding and multipath forwarding based inband probe for energy management in smart cities. IEEE Access 2018, 6, 39692-39704. [CrossRef]

85. Reka, S.S.; Dragicevic, T. Future effectual role of energy delivery: A comprehensive review of internet of things and smart grid. Renew. Sustain. Energy Rev. 2018, 91, 90-108. [CrossRef]

86. Markova, E.; Gudkova, I.; Ometov, A.; Dzantiev, I.; Andreev, S.; Koucheryavy, Y.; Samouylov, K. Flexible spectrum management in a smart city within licensed shared access framework. IEEE Access 2017, 5, 22252-22261. [CrossRef]

87. Carli, R.; Dotoli, M.; Cianci, E. An optimization tool for energy efficiency of street lighting systems in smart cities. IFAC-PapersOnLine 2017, 50, 14460-14464. [CrossRef]

88. Ullah, R.; Faheem, Y.; Kim, B.S. Energy and congestion-aware routing metric for smart grid ami networks in smart city. IEEE Access 2017, 5, 13799-13810. [CrossRef]

89. Garcia, V.J.; Braghirolli, L.F.; Barriquello, C.H.; Bernardon, D.P. A computational intelligence approach to improve the efficiency of repair services in the smart grid context. Comput. Electr. Eng. 2018, 70, 37-52. [CrossRef]

90. Di Santo, K.G.; Di Santo, S.G.; Monaro, R.M.; Saidel, M.A. Active demand side management for households in smart grids using optimization and artificial intelligence. Measurement 2018, 115, 152-161. [CrossRef] 
91. Garlik, B. The Application of Artificial Intelligence for Optimizing Energy Balance Energy Smart Buildings Integrated in the Smart Area. In Proceedings of the 2018 International Conference on Robots \& Intelligent System (ICRIS), Changsha, China, 26-27 May 2018; pp. 300-308. [CrossRef]

92. Calvillo, C.F.; Sánchez-Miralles, A.; Villar, J. Energy management and planning in smart cities. Renew. Sustain. Energy Rev. 2016, 55, 273-287. [CrossRef]

93. Liu, J.; Xiong, K.; Fan, P.; Zhong, Z. RF energy harvesting wireless powered sensor networks for smart cities. IEEE Access 2017, 5, 9348-9358. [CrossRef]

94. Jiang, X. Large scale air-quality monitoring in smart and sustainable cities. In Smart Cities: Foundations, Principles, and Applications; John Wiley \& Sons: Hoboken, NJ, USA, 2017; pp. 725-753. ISBN 9781119226444.

95. Tang, B.; Chen, Z.; Hefferman, G.; Pei, S.; Wei, T.; He, H.; Yang, Q. Incorporating intelligence in fog computing for big data analysis in smart cities. IEEE Trans. Ind. Inform. 2017, 13, 2140-2150. [CrossRef]

96. Bhati, A.; Hansen, M.; Chan, C.M. Energy conservation through smart homes in a smart city: A lesson for Singapore households. Energy Policy 2017, 104, 230-239. [CrossRef]

97. Hui, T.K.L.; Sherratt, R.S.; Sánchez, D.D. Major requirements for building smart homes in smart cities based on internet of things technologies. Futur. Gener. Comput. Syst. 2017, 76, 358-369. [CrossRef]

98. Uribe-Pérez, N.; Pous, C. A novel communication system approach for a smart city based on the human nervous system. Futur. Gener. Comput. Syst. 2017, 76, 314-328. [CrossRef]

99. Pouryazdan, M.; Kantarci, B.; Soyata, T.; Song, H. Anchor-assisted and vote-based trustworthiness assurance in smart city crowdsensing. IEEE Access 2016, 4, 529-541. [CrossRef]

100. Bibri, S.E. A foundational framework for smart sustainable city development: Theoretical, disciplinary, and discursive dimensions and their synergies. Sustain. Cities Soc. 2018, 38, 758-794. [CrossRef]

101. Hopkins, J.L.; McKay, J. Investigating 'anywhere working' as a mechanism for alleviating traffic congestion in smart cities. Technol. Forecast. Soc. Chang. 2018, 142, 258-272. [CrossRef]

102. Gutierrez, J.M.; Jensen, M.; Henius, M.; Riaz, T. Smart waste collection system based on location intelligence. Procedia Comput. Sci. 2015, 61, 120-127. [CrossRef]

103. Bibri, S.E. The IoT for smart sustainable cities of the future: An analytical framework for sensor-based big data applications for environmental sustainability. Sustain. Cities Soc. 2018, 38, 230-253. [CrossRef]

104. Duvier, C.; Anand, P.B.; Oltean-Dumbrava, C. Data quality and governance in a UK social housing initiative: Implications for smart sustainable cities. Sustain. Cities Soc. 2018, 39, 358-365. [CrossRef]

105. Butryn, K.; Jasińska, E.; Kovalyshyn, O.; Preweda, E. Sustainable formation of urban development on the example of the primary real estate market in Krakow. In Proceedings of the International Scientific Conference on Ecological and Environmental Engineering, EDP Sciences, Cracow, Poland, 26-29 June 2018; EDP Sciences: Les Ulis, France, 2019; Volume 86, p. 00010.

106. Lecomte, P. New boundaries: Conceptual framework for the analysis of commercial real estate in smart cities. J. Prop. Invest. Financ. 2019, 37, 118-135. [CrossRef]

107. Chen, Y.; Han, D. Water quality monitoring in smart city: A pilot project. Autom. Constr. 2018, 89, $307-316$. [CrossRef]

108. Ponte, B.; De La Fuente, D.; Pino, R.; Priore, P. Multiagent system for intelligent water demand management. In Proceedings of the IEEE International Conference on New Concepts in Smart Cities: Fostering Public and Private Alliances, Gijon, Spain, 11-13 December 2013.

109. Keung, K.L.; Lee, C.K.M.; Ng, K.K.H.; Yeung, C.K. Smart city application and analysis: Real-time urban drainage monitoring by IoT sensors: A case study of Hong Kong. In Proceedings of the IEEE International Conference on Industrial Engineering and Engineering Management, Bangkok, Thailand, 16-19 December 2018; IEEE Computer Society: New York, NY, USA, 2019; pp. 521-525.

110. Malik, H.; Kändler, N.; Alam, M.M.; Annus, I.; Le Moullec, Y.; Kuusik, A. Evaluation of low power wide area network technologies for smart urban drainage systems. In Proceedings of the IEEE International Conference on Environmental Engineering, Milan, Italy, 12-14 March 2018; Institute of Electrical and Electronics Engineers Inc.: Milan, Italy, 2018; pp. 1-5.

111. Ramos, H.M.; McNabola, A.; López-Jiménez, P.A.; Pérez-Sánchez, M. Smart water management towards future water sustainable networks. Water 2019, 12, 58. [CrossRef]

112. Rego, A.; Garcia, L.; Sendra, S.; Lloret, J. Software defined network-based control system for an efficient traffic management for emergency situations in smart cities. Futur. Gener. Comput. Syst. 2018, 88, $243-253$. [CrossRef] 
113. Alamaniotis, M.; Tsoukalas, L. Fuzzy multi-kernel approach in intelligent control of energy consumption in smart cities. In Proceedings of the IEEE International Conference on Tools with Artificial Intelligence, Boston, MA, USA, 6-8 November 2017; pp. 1021-1028.

114. Alvi, A.N.; Bouk, S.H.; Ahmed, S.H.; Yaqub, M.A.; Sarkar, M.; Song, H. BEST-MAC: Bitmap-assisted efficient and scalable TDMA-based WSN MAC protocol for smart cities. IEEE Access 2016, 4, 312-322. [CrossRef]

115. Sharma, P.K.; Park, J.H. Blockchain based hybrid network architecture for the smart city. Futur. Gener. Comput. Syst. 2018, 86, 650-655. [CrossRef]

116. González-Landero, F.; García-Magariño, I.; Lacuesta, R.; Lloret, J. PriorityNet app: A mobile application for establishing priorities in the context of 5G ultra-dense networks. IEEE Access 2018, 6, 14141-14150. [CrossRef]

117. Al-Turjman, F. Mobile couriers' selection for the smart-grid in smart-cities' pervasive sensing. Futur. Gener. Comput. Syst. 2018, 82, 327-341. [CrossRef]

118. Hashem, I.A.T.; Chang, V.; Anuar, N.B.; Adewole, K.; Yaqoob, I.; Gani, A.; Ahmed, E.; Chiroma, H. The role of big data in smart city. Int. J. Inf. Manag. 2016, 36, 748-758. [CrossRef]

119. Park, C.M.; Rehman, R.A.; Kim, B. Packet flooding mitigation in CCN-based wireless multimedia sensor networks for smart cities. IEEE Access 2017, 5, 11054-11062. [CrossRef]

120. Fuertes, G.; Soto, I.; Vargas, M.; Valencia, A.; Sabattin, J.; Carrasco, R. Nanosensors for a monitoring system in intelligent and active packaging. J. Sensors 2016, 1-8. [CrossRef]

121. Brock, K.; den Ouden, E.; van der Klauw, K.; Podoynitsyna, K.; Langerak, F. Light the way for smart cities: Lessons from Philips Lighting. Technol. Forecast. Soc. Chang. 2018, 142, 194-209. [CrossRef]

122. Nitoslawski, S.A.; Galle, N.J.; van den Bosc, C.K.; Steenberg, J.W.N. Smarter ecosystems for smarter cities? a review of trends, technologies, and turning points for smart urban forestry. Sustain. Cities Soc. 2019, 51, 101770. [CrossRef]

123. Artmann, M.; Kohler, M.; Meinel, G.; Gan, J.; Ioja, I.C. How smart growth and green infrastructure can mutually support each other-A conceptual framework for compact and green cities. Ecol. Indic. 2019, 96, 10-22. [CrossRef]

124. Gupta, K.; Puntambekar, K.; Roy, A.; Pandey, K.; Mahavir; Kumar, P. Smart environment through smart tools and technologies for urban green spaces. In Smart Environment for Smart Cities; Springer: Singapore, 2020; pp. 149-194.

125. Hardy, A.; Aryal, J. Using innovations to understand tourist mobility in national parks. J. Sustain. Tour. 2020, 28, 263-283. [CrossRef]

126. Kummitha, R.K.R. Entrepreneurial urbanism and technological panacea: Why smart city planning needs to go beyond corporate visioning? Technol. Forecast. Soc. Change 2018, 137, 330-339. [CrossRef]

127. Makridakis, S. The forthcoming artificial intelligence (AI) revolution: Its impact on society and firms. Futures 2017, 90, 46-60. [CrossRef]

128. Tao, F.; Qi, Q.; Liu, A.; Kusiak, A. Data-driven smart manufacturing. J. Manuf. Syst. 2018, 48, 157-169. [CrossRef]

129. Ruan, L.; Li, C.; Zhang, Y.; Wang, H. Soft computing model based financial aware spatiotemporal social network analysis and visualization for smart cities. Comput. Environ. Urban Syst. 2018, 77, 1-14. [CrossRef]

130. Du, J.; Zhu, Q.; Shi, Y.; Wang, Q.; Lin, Y.; Zhao, D. Cognition digital twins for personalized information systems of smart cities: Proof of concept. J. Manag. Eng. 2020, 36, 04019052-1-04019052-17. [CrossRef]

131. Zhang, Y.; Xiong, Z.; Niyato, D.; Wang, P.; Han, Z. Information trading in internet of things for smart cities: A market-oriented analysis. IEEE Netw. 2020, 34, 122-129. [CrossRef]

132. Lv, Z.; Li, X.; Zhang, B.; Wang, W.; Zhu, Y.; Hu, J.; Feng, S. Managing big city information based on WebVRGIS. IEEE Access 2016, 4, 407-415. [CrossRef]

133. Kumar, H.; Singh, M.K.; Gupta, M.P.; Madaan, J. Moving towards smart cities: Solutions that lead to the smart city transformation framework. Technol. Forecast. Soc. Chang. 2018, 153, 1-16. [CrossRef]

134. Jara, A.J.; Bocchi, Y.; Genoud, D. Determining human dynamics through the internet of things. In Proceedings of the IEEE International Joint Conference on Web Intelligence and Intelligent Agent Technology, Atlanta, GA, USA, 17-20 November 2013; Volume 3, pp. 109-113.

135. Puiu, D.; Barnaghi, P.; Tönjes, R.; Kümper, D.; Ali, M.I.; Mileo, A.; Parreira, J.X.; Fischer, M.; Kolozali, S.; Farajidavar, N.; et al. CityPulse: Large scale data analytics framework for smart cities. IEEE Access 2016, 4, 1086-1108. [CrossRef]

136. Wan, S.; Lu, J.; Fan, P.; Letaief, K.B. To smart city: Public safety network design for emergency. IEEE Access 2017, 6, 1451-1460. [CrossRef] 
137. Huang, C.D.; Goo, J.; Nam, K.; Yoo, C.W. Smart tourism technologies in travel planning: The role of exploration and exploitation. Inf. Manag. 2017, 54, 757-770. [CrossRef]

138. Sun, Y.; Song, H.; Jara, A.J.; Bie, R. Internet of things and big data analytics for smart and connected communities. IEEE Access 2016, 4, 766-773. [CrossRef]

139. Buhalis, D.; Leung, R. Smart hospitality-Interconnectivity and interoperability towards an ecosystem. Int. J. Hosp. Manag. 2018, 71, 41-50. [CrossRef]

140. Brisimi, T.S.; Cassandras, C.G.; Osgood, C.; Paschalidis, I.C.; Zhang, Y. Sensing and classifying roadway obstacles in smart cities: The street bump system. IEEE Access 2016, 4, 1301-1312. [CrossRef]

141. Qiu, J.; Du, L.; Zhang, D.; Su, S.; Tian, Z. Nei-TTE: Intelligent traffic time estimation based on fine-grained time derivation of road segments for smart city. IEEE Trans. Ind. Inf. 2020, 16, 2659-2666. [CrossRef]

142. Al-Turjman, F. Vehicular speed learning in the future smart-cities' paradigm. In Proceedings of the 2017 IEEE 42 nd Conference on Local Computer Networks Workshops (LCN Workshops), Singapore, 9 October 2017; pp. 61-65. [CrossRef]

143. Meena, N.K.; Parashar, S.; Swarnkar, A.; Gupta, N.; Niazi, K.R.; Bansal, R.C. Mobile power infrastructure planning and operational management for smart city applications. Energy Procedia 2017, 142, 2202-2207. [CrossRef]

144. Iqbal, M.M.; Mehmood, M.T.; Jabbar, S.; Khalid, S.; Ahmad, A.; Jeon, G. An enhanced framework for multimedia data: Green transmission and portrayal for smart traffic system. Comput. Electr. Eng. 2018, 67, 291-308. [CrossRef]

145. Elshenawy, M.; Abdulhai, B.; El-Darieby, M. Towards a service-oriented cyber-physical systems of systems for smart city mobility applications. Futur. Gener. Comput. Syst. 2018, 79, 575-587. [CrossRef]

146. Gohar, M.; Muzammal, M.; Ur Rahman, A. Smart TSS: Defining transportation system behavior using big data analytics in smart cities. Sustain. Cities Soc. 2018, 41, 114-119. [CrossRef]

147. Raman, R.; Sa, P.K.; Majhi, B.; Bakshi, S. Direction estimation for pedestrian monitoring system in smart cities: An HMM based approach. IEEE Access 2016, 4, 5788-5808. [CrossRef]

148. Sarangi, M.; Mohapatra, S.; Tirunagiri, S.V.; Das, S.K.; Babu, K.S. IoT aware automatic smart parking system for smart city. In Proceedings of the Cognitive Informatics and Soft Computing, Rajampet, India, 9-10 April 2019; Springer: New York, NY, USA, 2020; pp. 469-481.

149. Saleem, A.A.; Siddiqui, H.U.R.; Shafique, R.; Haider, A.; Ali, M. A review on smart IOT based parking system. In Proceedings of the International Conference on Soft Computing and Data Mining, Langkawi, Malaysia, 22-23 January 2020; Springer: New York, NY, USA, 2020; Volume 978, pp. 264-273.

150. Kelimeler, A. Smart city application: Android based smart parking system. In Proceedings of the IEEE International Artificial Intelligence and Data Processing Symposium, Malatya, Turkey, 16-17 September 2017; pp. 1-4.

151. Nagaraj, S.; Muthiyan, B.; Ravi, S.; Menezes, V.; Kapoor, K.; Jeon, H. Edge-based street object detection. In Proceedings of the 2017 IEEE SmartWorld, Ubiquitous Intelligence \& Computing, Advanced \& Trusted Computed, Scalable Computing \& Communications, Cloud \& Big Data Computing, Internet of People and Smart City Innovation, San Francisco, CA, USA, 4-8 August 2017; pp. 1-4. [CrossRef]

152. Lyons, G. Getting smart about urban mobility-aligning the paradigms of smart and sustainable. Transp. Res. Part A Policy Pract. 2018, 115, 4-14. [CrossRef]

153. Nowakowski, P.; Szwarc, K.; Boryczka, U. Vehicle route planning in e-waste mobile collection on demand supported by artificial intelligence algorithms. Transp. Res. Part D Transp. Environ. 2018, 63, 1-22. [CrossRef]

154. Aguaded-Ramírez, E. Smart city and intercultural education. Procedia Soc. Behav. Sci. 2017, 237, $326-333$. [CrossRef]

155. Birtchnell, T.; Elliott, A. Automating the black art: Creative places for artificial intelligence in audio mastering. Geoforum 2018, 96, 77-86. [CrossRef]

156. Fuertes, G.; Krommenacker, N.; Soto, I.; Osorio-Valenzuela, L.; Carrasco, R. Nanosensory wireless network applied to monitoring the migration phenomenon in plastic containers. Int. J. Sensors, Wirel. Commun. Control 2014, 4, 96-102. [CrossRef]

157. Baudier, P.; Ammi, C.; Deboeuf-Rouchon, M. Smart home: Highly-educated students' acceptance. Technol. Forecast. Soc. Chang. 2018, 1-19. [CrossRef]

158. Prieto, A.; Atencia, M.; Sandoval, F. Advances in artificial neural networks and machine learning. Neurocomputing 2013, 121, 1-4. [CrossRef] 
159. Muhammed, T.; Mehmood, R.; Albeshri, A.; Katib, I. UbeHealth: A personalized ubiquitous cloud and edge-enabled networked healthcare system for smart cities. IEEE Access 2018, 6, 32258-32285. [CrossRef]

160. Muhammad, G.; Alsulaiman, M.; Amin, S.U.; Ghoneim, A.; Alhamid, M.F. A facial-expression monitoring system for improved healthcare in smart cities. IEEE Access 2017, 5, 10871-10881. [CrossRef]

161. Aborokbah, M.M.; Al-Mutairi, S.; Sangaiah, A.K.; Samuel, O.W. Adaptive context aware decision computing paradigm for intensive health care delivery in smart cities-A case analysis. Sustain. Cities Soc. 2018, 41, 919-924. [CrossRef]

162. Pramanik, M.I.; Lau, R.Y.K.; Demirkan, H.; Azad, M.A.K. Smart health: Big data enabled health paradigm within smart cities. Expert Syst. Appl. 2017, 87, 370-383. [CrossRef]

163. Sajjad, M.; Khan, S.; Jan, Z.; Muhammad, K.; Moon, H.; Kwak, J.T.; Rho, S.; Baik, S.W.; Mehmood, I. Leukocytes classification and segmentation in microscopic blood smear: A resource-aware healthcare service in smart cities. IEEE Access 2017, 5, 3475-3489. [CrossRef]

164. Beltran-Ramirez, R.; Maciel-Arellano, R.; Gomez-Barba, L.; Stokes, L.; Gonzalez-Sandoval, C. Mobile applications utilized for the prevention of potential epidemics in smart cities. In Proceedings of the IEEE International Smart Cities Conference, Guadalajara, Mexico, 25-28 October 2015; pp. 75-78.

165. Ray, A.; Bala, P.K.; Dasgupta, S.A.; Sivasankaran, N. Factors influencing adoption of e-services in rural India-perspectives of consumers and service providers. J. Indian Bus. Res. 2019. [CrossRef]

166. Urbieta, A.; González-Beltrán, A.; Ben Mokhtar, S.; Anwar Hossain, M.; Capra, L. Adaptive and context-aware service composition for IoT-based smart cities. Futur. Gener. Comput. Syst. 2017, 76, 262-274. [CrossRef]

167. Campbell, H.A.; Delashmutt, M.W. Studying technology and ecclesiology in online multi-site worship. J. Contemp. Relig. 2014, 29, 267-285. [CrossRef]

168. Scalenghe, R.; Pantani, O.-L. Connecting existing cemeteries saving good soils (for livings). Sustainability 2019, 12, 93. [CrossRef]

169. Tang, X.; Xu, X.; Svensson, T.; Tao, X. Coverage performance of joint transmission for moving relay enabled cellular networks in dense urban scenarios. IEEE Access 2017, 5, 13001-13009. [CrossRef]

170. Zaid, A.A.; Suhweil, Y.; Yaman, M.A. Smart controlling for traffic light time. In Proceedings of the IEEE Jordan Conference on Applied Electrical Engineering and Computing Technologies, Aqaba, Jordan, 11-13 October 2017; pp. 1-5.

171. Das, D.K.; Sonar, S.G. Exploring dimensions and elements for smart city development in India. In Urbanization and Regional Sustainability in South Asia; Springer: Cham, Switzerland, 2020; pp. 245-259.

172. Jucevičius, R.; Patašienè, I.; Patašius, M. Digital dimension of smart city: Critical analysis. Procedia Soc. Behav. Sci. 2014, 156, 146-150. [CrossRef]

173. Ulrich, J.; Gattass e Silva, L.; Maciel, C. A systematic review on IoT and e-services co-production. In Proceedings of the International Conference on Information Technology \& Systems, Bogota, Colombia, 5-7 February 2020; Springer: Cham, Switzerland, 2020; pp. 14-23.

174. Pappel, I.; Tsap, V.; Pappel, I.; Draheim, D. Exploring e-services development in local government authorities by means of electronic document management systems. In Proceedings of the International Conference on Electronic Governance and Open Society: Challenges in Eurasia, Saint Petersburg, Russia, 13-14 November 2019; Springer: New York, NY, USA, 2019; Volume 947, pp. 223-234.

175. Chen, C.; Pan, S. Using the crowd of taxis to last mile delivery in e-commerce: A methodological research. In Service Orientation in Holonic and Multi-Agent Manufacturing; Springer: Cham, Switzerland, 2016; p. 3408, ISBN 9783319303376.

176. Bagozi, A.; Bianchini, D.; De Antonellis, V.; Garda, M.; Melchiori, M. Services as enterprise smart contracts in the digital factory. In Proceedings of the IEEE International Conference on Web Services, Milan, Italy, 8-13 July 2019; Institute of Electrical and Electronics Engineers Inc.: New York, NY, USA, 2019; pp. 224-228.

177. Aheleroff, S.; Xu, X.; Lu, Y.; Aristizabal, M.; Velásquez, J.P.; Joa, B.; Valencia, Y. IoT-enabled smart appliances under industry 4.0: A case study. Adv. Eng. Inform. 2020, 43, 101043.1-101043.14. [CrossRef]

178. Terziyan, V.; Gryshko, S.; Golovianko, M. Patented intelligence: Cloning human decision models for industry 4.0. J. Manuf. Syst. 2018, 48, 204-217. [CrossRef]

179. Abbate, T.; Cesaroni, F.; Cinici, M.C.; Villari, M. Business models for developing smart cities. A fuzzy set qualitative comparative analysis of an IoT platform. Technol. Forecast. Soc. Chang. 2018, 142, 183-193. [CrossRef]

180. Pantano, E.; Timmermans, H. What is smart for retailing? Procedia Environ. Sci. 2014, 22, 101-107. [CrossRef] 
181. van den Buuse, D.; Kolk, A. An exploration of smart city approaches by international ICT firms. Technol. Forecast. Soc. Chang. 2018, 142, 220-234. [CrossRef]

182. Murtadho, F.; Sudiharto, D.W.; Wijiutomo, C.W.; Ariyanto, E. Design and implementation of smart advertisement display board prototype. In Proceedings of the IEEE International Seminar on Application for Technology of Information and Communication, Semarang, Indonesia, 21-22 September 2019; Institute of Electrical and Electronics Engineers Inc.: New York, NY, USA, 2019; pp. 246-250.

183. Qin, X.; Jiang, Z. The impact of AI on the advertising process: The Chinese experience. J. Advert. 2019, 48, 338-346. [CrossRef]

184. Niaros, V.; Kostakis, V.; Drechsler, W. Making (in) the smart city: The emergence of makerspaces. Telemat. Inform. 2017, 34, 1143-1152. [CrossRef]

185. Scott, H.; Hoon, H.J. Industry mix and 3D urban heterogeneity: Insights into innovation districts. Procedia Eng. 2017, 198, 549-561. [CrossRef]

186. Ahmed, S.H.; Rani, S. A hybrid approach, smart street use case and future aspects for internet of things in smart cities. Futur. Gener. Comput. Syst. 2018, 79, 941-951. [CrossRef]

187. Osman, A.M.S. A novel big data analytics framework for smart cities. Futur. Gener. Comput. Syst. 2018, 91, 620-633. [CrossRef]

188. Tompson, T. Understanding the contextual development of smart city initiatives: A pragmatist methodology. She Ji J. Des. Econ. Innov. 2017, 3, 210-228. [CrossRef]

189. Mahalakshmi, J.; Kuppusamy, K.; Kaleeswari, C.; Maheswari, P. IoT sensor-based smart agricultural system. In Emerging Technologies for Agriculture and Environment; Springer: Singapore, 2020; pp. 39-52.

190. Wang, H.; Qin, H.; Zhao, M.; Wei, X.; Shen, H.; Susilo, W. Blockchain-based fair payment smart contract for public cloud storage auditing. Inf. Sci. 2020, 519, 348-362. [CrossRef]

191. Suliman, A.; Husain, Z.; Abououf, M.; Alblooshi, M.; Salah, K. Monetization of IoT data using smart contracts. IET Netw. 2019, 8, 32-37. [CrossRef]

192. Liu, H.; Deng, Y.; Guo, D.; Fang, B.; Sun, F.; Yang, W. An interactive perception method for warehouse automation in smart cities. IEEE Trans. Ind. Inform. 2020, 1-9. [CrossRef]

193. Küfner, T.; Uhlemann, T.H.J.; Ziegler, B. Lean data in manufacturing systems: Using artificial intelligence for decentralized data reduction and information extraction. Procedia CIRP 2018, 72, 219-224. [CrossRef]

194. Adapa, S. Indian smart cities and cleaner production initiatives-Integrated framework and recommendations. J. Clean. Prod. 2018, 172, 3351-3366. [CrossRef]

195. Edgar, T.F.; Pistikopoulos, E.N. Smart manufacturing and energy systems. Comput. Chem. Eng. 2018, 114, 130-144. [CrossRef]

196. Rjab, A.B.; Mellouli, S. Artificial intelligence in smart cities: Systematic literature network analysis. In $A C M$ International Conference Proceeding Series; Association for Computing Machinery: New York, NY, USA, 2019; pp. 259-269.

Publisher's Note: MDPI stays neutral with regard to jurisdictional claims in published maps and institutional affiliations.

(C) 2020 by the authors. Licensee MDPI, Basel, Switzerland. This article is an open access article distributed under the terms and conditions of the Creative Commons Attribution (CC BY) license (http://creativecommons.org/licenses/by/4.0/). 